REMOTE SENSNG LABORATORY

OPERATED BY BECHTEL NEVADA

FOR THE U.S. DEPARTMENT OF ENERGY

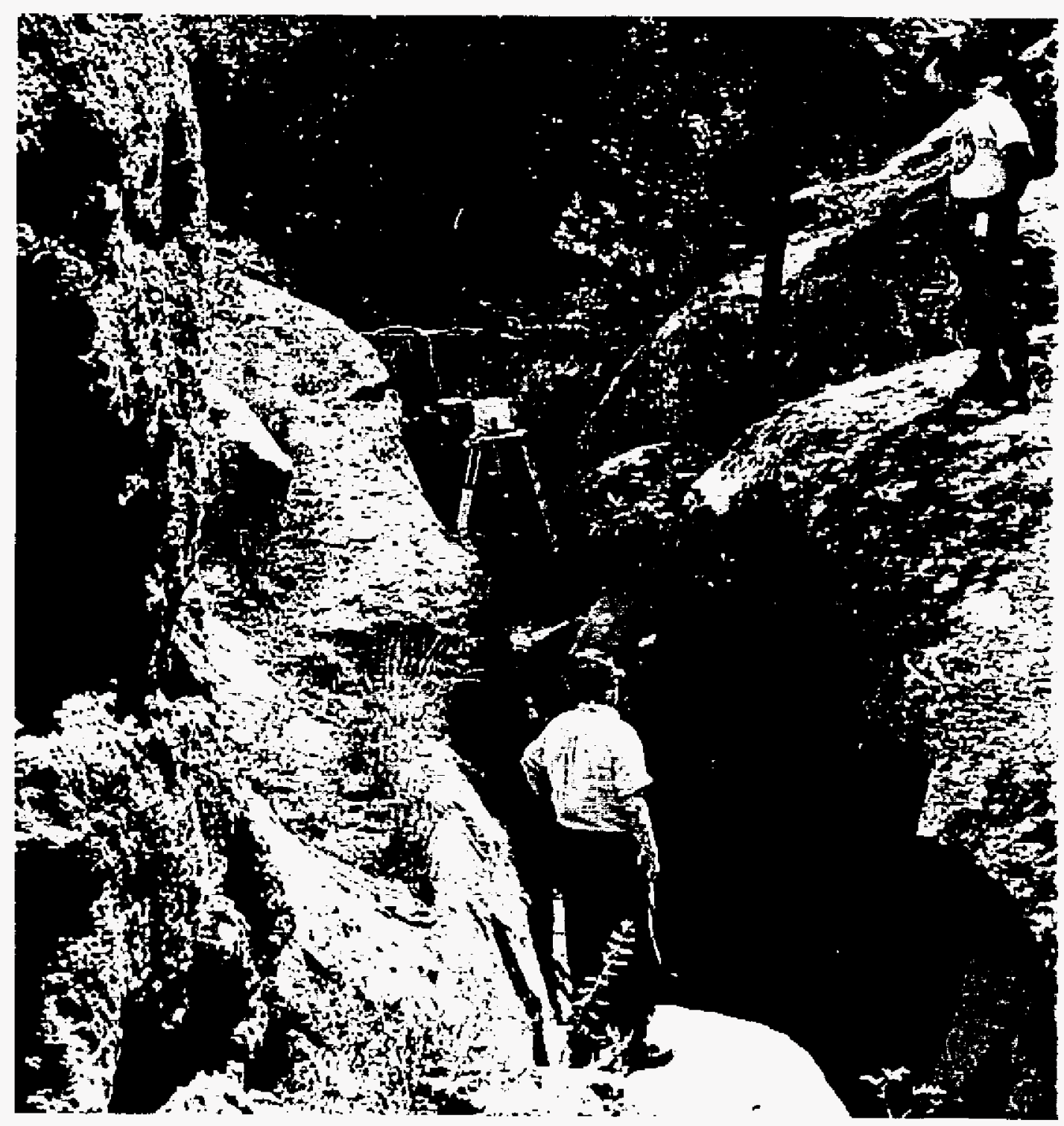

\title{
AN IN SITU RADIOLOGICAL SURVEY OF THREE CANYONS AT THE LOS ALAMOS NATIONAL LABORATORY
}

LOS ALAMOS, NEW MEXICO

DATE OF SURVEY: AUGUST 19-30, 1996

\author{
R. J. Maurer \\ Bechtel Nevada \\ Las Vegas, Nevada
}

Approved for Public Release; Future Dissemination Unlimited 


\section{DISCLAIMER}

This report was prepared as an account of work sponsored by an agency of the United States Government. Neither the United States Government nor an agency thereof, nor any of their employees, nor any of their contractors and subcontractors, or their employees, makes a warranty, express or implied, or assumes legal liability or responsibility for the accuracy, completeness, or any third party's use or the results of such use of any disclosed information, apparatus, product, or process or represents that its use would not infringe privately owned rights. Reference herein to any specific commercial product, process, or service by trade name, trademark, manufacturer, or otherwise, does not necessarily constitute or imply an endorsement, recommendation, or favoring by the United States government or an agency thereof or its contractors or subcontractors. The views and opinions of the authors expressed herein do not necessarily state or reflect those of the United States Government or an agency thereot.

Available electronically at http://www.doe.gov/bridge.

Available for a processing fee to the U.S. Department of Energy and its contractors in paper from the -

U.S. Department of Energy

Office of Scientific and Technical Information

P.O. Box 62

Oak Ridge, TN 37831-0062

Telephone: 865.576 .8401

Fax: 865.576.5728

Email: reports@adonis.osti.gov

Available for sale to the public in paper from the -

U.S. Department of Commerce

National Technical Information Service

5285 Port Royal Road

Springfield, VA 22161

Telephone: 800.553.6847

Fax: 703.605.6900

Email: orders@ntis.fedworld.gov

Online ordering: http://www.ntis.gov/ordering.htm 


\title{
AN IN SITU RADIOLOGICAL SURVEY OF THREE CANYONS AT THE LOS ALAMOS NATIONAL LABORATORY
}

\author{
LOS ALAMOS, NEW MEXICO
}

DATE OF SURVEY: AUGUST 19-30, 1996

\author{
R. J. Maurer
}

Project Scientist

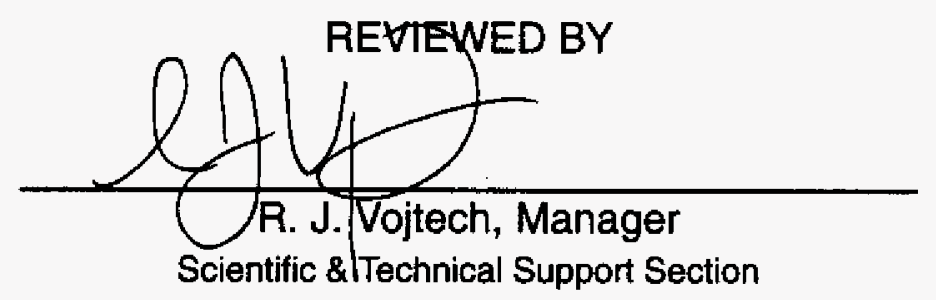

This Document is UNCLASSIFIED

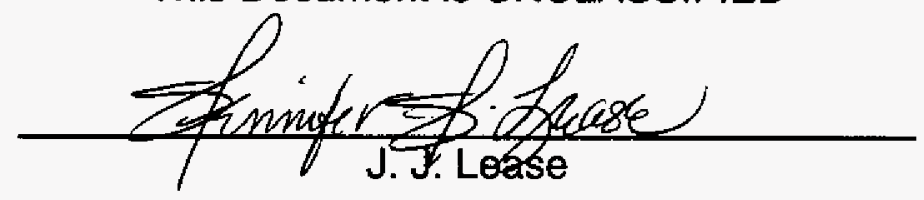

Authorized Derivative Classifier 


\begin{abstract}
An in situ radiological survey of Mortandad, Ten Site, and DP Canyons at the Los Alamos National Laboratory was conducted during August 19-30,1996. The purpose of this survey was to measure the quantities of radionuclides that remain in the canyons from past laboratory operations. A total of 65 in situ measurements were conducted using high-resolution gamma radiation detectors at 1 meter above the ground. The measurements were obtained in the streambeds of the canyons beginning near the water-release points at the laboratories and extending to the ends of the canyons. Three man-made gamma-emitting radionuclides were detected in the canyons: americium-241 $\left({ }^{241} \mathrm{Am}\right)$, cesium-137 $\left({ }^{137} \mathrm{Cs}\right)$, and cobalt-60 $\left({ }^{60} \mathrm{Co}\right)$. Estimated contamination levels ranged from $13.3-290.4$ picocuries per gram $(\mathrm{pCi} / \mathrm{g})$ for ${ }^{241} \mathrm{Am}, 4.4-327.8 \mathrm{pCi} / \mathrm{g}$ for ${ }^{137} \mathrm{Cs}$, and $0.4-2.6 \mathrm{pCi} / \mathrm{g}$ for ${ }^{60} \mathrm{Co}$.
\end{abstract}




\section{CONTENTS}

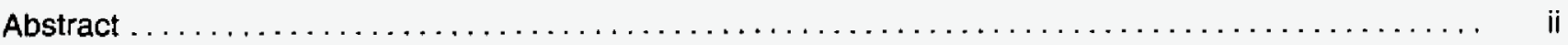

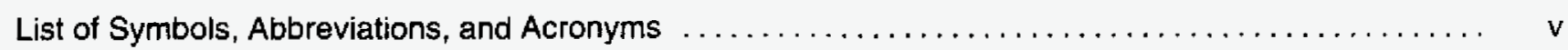

\section{Sections}

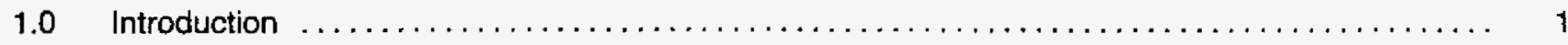

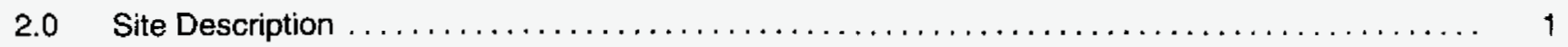

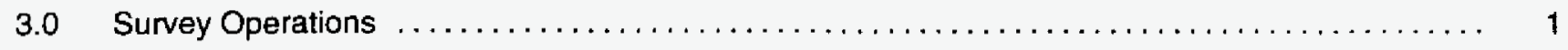

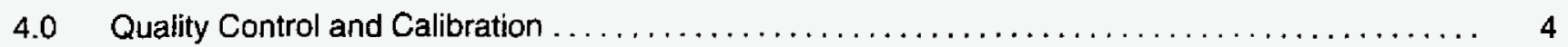

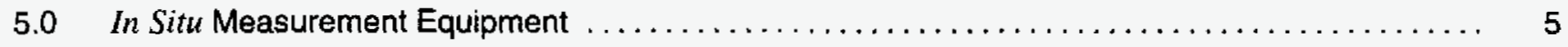

5.1 HPGe Detector System $\ldots \ldots \ldots \ldots \ldots \ldots \ldots \ldots \ldots \ldots \ldots \ldots \ldots \ldots \ldots \ldots \ldots \ldots \ldots$

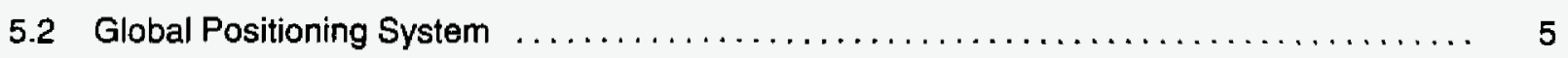

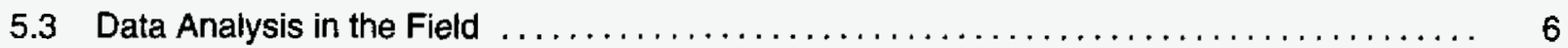

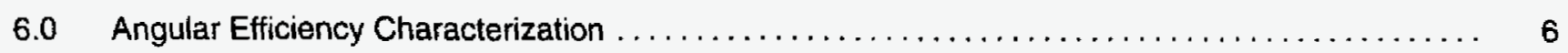

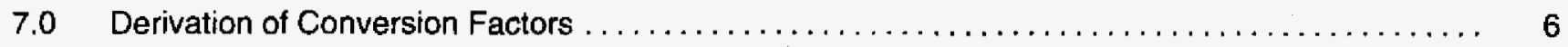

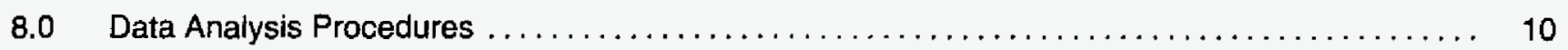

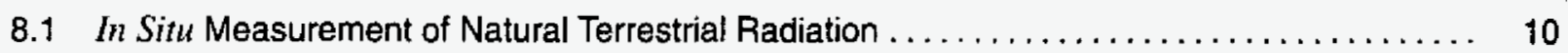

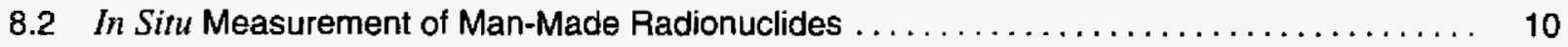

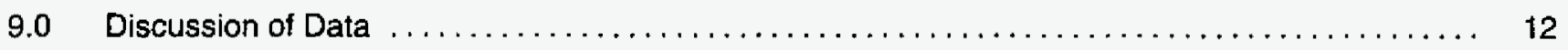

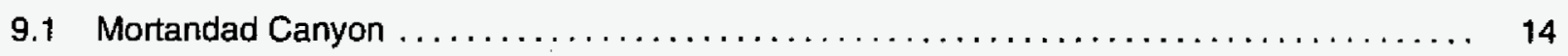

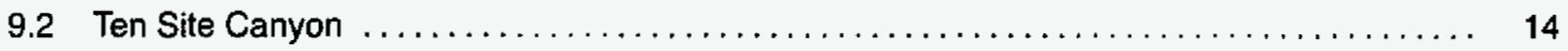

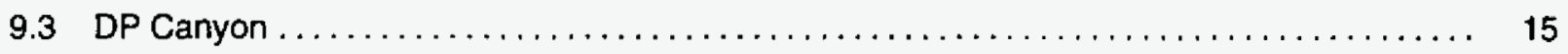

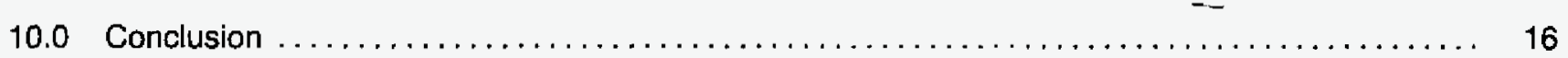

\section{Figures}

1 Map of Mortandad and Ten Site Canyons Showing the Locations

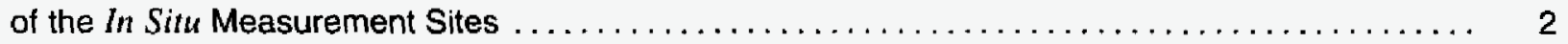

2 Map of DP Canyon Showing the Locations of the In Situ Measurement Sites .............

3 Typical HPGe Quality Control Gamma-Ray Spectrum $\ldots \ldots \ldots \ldots \ldots \ldots \ldots \ldots \ldots$

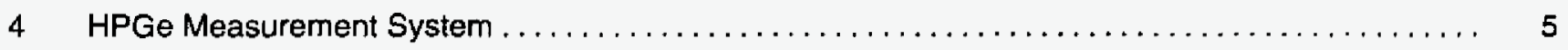




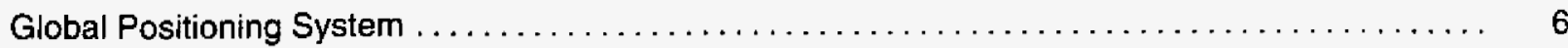

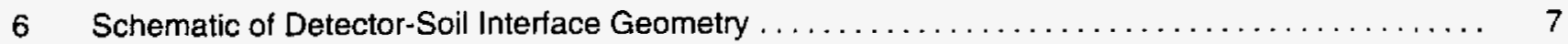

7 Typical HPGe Natural Terrestrial Gamma-Ray Spectrum $\ldots \ldots \ldots \ldots \ldots \ldots \ldots \ldots \ldots \ldots \ldots \ldots \ldots$

8 Typical HPGe Gamma-Ray Spectrum from Mortandad Canyon (Site 19) $\ldots \ldots \ldots \ldots \ldots \ldots \ldots$

\section{Tables}

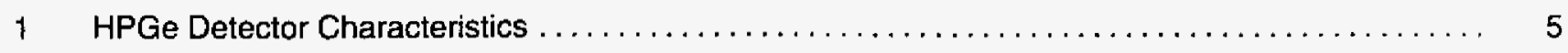

2 Conversion Factors for Natural Radionuclides (pCi/g per $\mathrm{cps}) \ldots \ldots \ldots \ldots \ldots \ldots \ldots \ldots \ldots \ldots$

3 Conversion Factors for Radionuclide Distributions (HPGe S/N 34TN30888) $\ldots \ldots \ldots \ldots \ldots \ldots .9$

4 Conversion Factors for Radionuclide Distributions (HPGe S/N 34TN20879) $\ldots \ldots \ldots \ldots \ldots \ldots \ldots$

$5 \quad$ Natural Terrestrial Radiation in HPGe In Situ Measurements $\ldots \ldots \ldots \ldots \ldots \ldots \ldots \ldots \ldots \ldots \ldots \ldots \ldots$

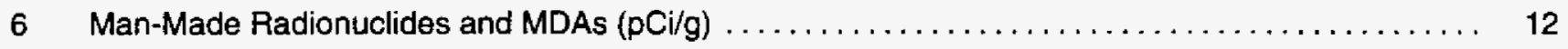

$7 \quad$ Soil Activity Concentration for In Situ Data at Mortandad Canyon $\ldots \ldots \ldots \ldots \ldots \ldots \ldots \ldots \ldots$

8 Soil Activity Concentration for In Situ Data at Ten Site Canyon $\ldots \ldots \ldots \ldots \ldots \ldots \ldots \ldots \ldots \ldots$

$9 \quad$ Soil Activity Concentration for $\ln$ Situ Data at DP Canyon $\ldots \ldots \ldots \ldots \ldots \ldots \ldots \ldots \ldots \ldots \ldots$

\section{Appendix}

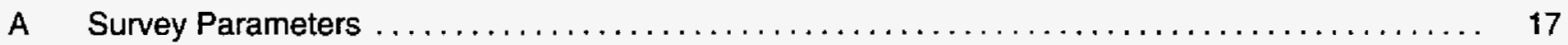

References $\ldots \ldots \ldots \ldots \ldots \ldots \ldots \ldots \ldots \ldots \ldots \ldots \ldots \ldots \ldots \ldots \ldots \ldots \ldots \ldots \ldots \ldots \ldots \ldots \ldots \ldots \ldots, 18$ 


\section{LIST OF SYMBOLS, ABBREVIATIONS, AND ACRONYMS}

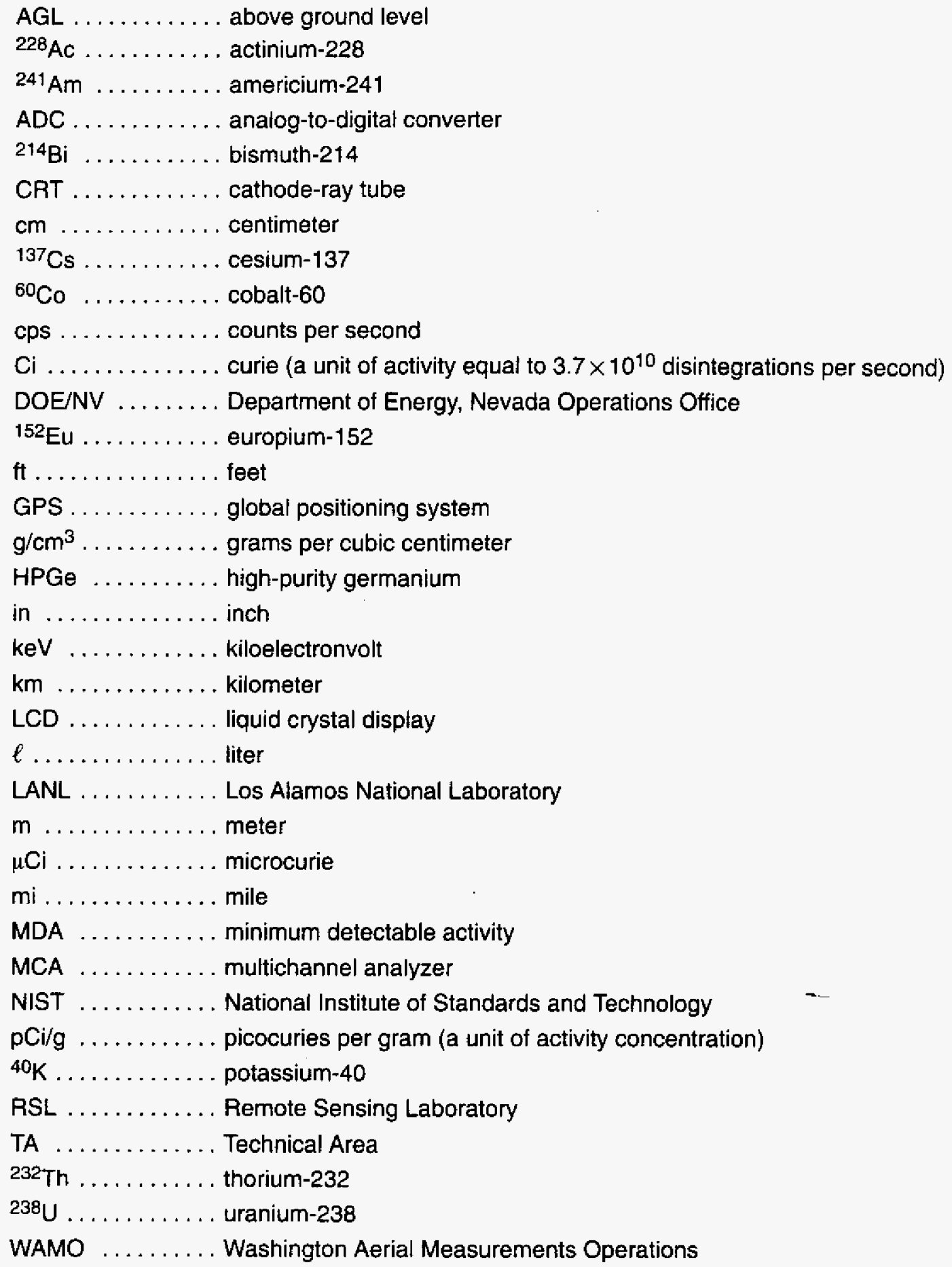




\subsection{INTRODUCTION}

An in situ radiological survey of Mortandad, Ten Site, and DP Canyons was conducted at the Los Alamos National Laboratory (LANL) in Los Alamos, New Mexico, during August 19-30, 1996. The measurements were conducted by a field team from the Washington Aerial Measurements Operations (WAMO) office located at Andrews Air Force Base near Washington, D.C. The WAMO office is part of the Remote Sensing Laboratory (RSL) located in Las Vegas, Nevada, and is operated by Bechtel Nevada for the U.S. Department of Energy, Nevada Operations Office (DOE/NV). The survey was conducted at the request of the DOE/NV in support of the LANL environmental remediation and restoration program. A total of 65 in situ measurements were conducted during the twoweek survey.

\subsection{SITE DESCRIPTION}

LANL was built in the 1940s as part of the Manhattan Project. Many of the laboratory's technical areas are situated along the mesas of a volcanic field. The areas surveyed were the regions of Mortandad, Ten Site, and DP Canyons that lie between the mesas where the technical areas are located.

Mortandad Canyon is located along Pajarito Road and begins north of Technical Area-55 (TA-55) and extends east $3.2 \mathrm{mi}(5.2 \mathrm{~km})$ to the laboratory boundary bordering the San Ildefonso Indian Reservation. The canyon width varies from a very narrow $50 \mathrm{ft}$ $(15 \mathrm{~m})$ near TA-55 to more than $1,500 \mathrm{ft}(460 \mathrm{~m})$ at the laboratory boundary. A streambed (usually dry) traverses the entire length of the canyon beginning with a trench near TA-55 ( $6 \mathrm{ft}$ wide by $4 \mathrm{ft}$ deep) ( 1.8 by $1.2 \mathrm{~m}$ ) and gradually widening to a broad, shallow trough $(20-30 \mathrm{ft}[6-9 \mathrm{~m}]$ wide $)$ at the laboratory boundary. Under permit, the facilities upstream discharge several million gallons of waste water annually into the canyon.

Ten Site Canyon is located along Pajarito Road and begins south of TA-35. The canyon is $0.7 \mathrm{mi}(1.1 \mathrm{~km})$ long. The canyon width varies from a very narrow $30 \mathrm{ft}$ $(9 \mathrm{~m})$ near the TA-35 waste-water facility to about $1,000 \mathrm{ft}(305 \mathrm{~m})$ at the confluence with Mortandad Canyon. A shallow, streambed traverses the entire length of the canyon.

DP Canyon is located south of the Los Alamos Airport and runs parallel to the airport runway. The canyon begins east of Trinity Drive and extends approximately $2.2 \mathrm{mi}(3.5 \mathrm{~km})$ to Los Alamos Canyon. DP Canyon extends east, north of industrial park on DP Road and the TA-21 complex. The canyon is about $100 \mathrm{ft}(31 \mathrm{~m})$ wide at the upper section and becomes very rugged and rocky as it descends approximately $100 \mathrm{ft}(31 \mathrm{~m})$ into the Los Alamos Canyon. A streambed traverses the entire length of DP Canyon beginning with a trench $6 \mathrm{ft}(1.8 \mathrm{~m})$ wide by $4 \mathrm{ft}(1.2 \mathrm{~m})$ deep that increases in size to a rocky ravine $12 \mathrm{ft}$ ( 3.7 $\mathrm{m})$ wide by $20 \mathrm{ft}(6 \mathrm{~m})$ deep.

\subsection{SURVEY OPERATIONS}

The purpose of the survey was to measure the small quantities of radionuclides that have been released from past laboratory operations and have migrated downstream over the years with the occasional waste-water discharges and heavy rainfall. Initial measurement sites for Mortandad, Ten Site, and DP Canyons were provided by laboratory personnel for purposes of planning the survey. In principle, the plan ${ }^{1}$ was to conduct measurements every $1,000 \mathrm{tt}(305 \mathrm{~m})$ along the streambeds from the beginning to the end of the canyon. Figure 1 is a topographic map of Mortandad and Ten Site Canyons showing the measurement sites. Figure 2 is a topographic map of DP Canyon showing the measurement sites. For each topographic map, the measurement sites are numbered and color-coded. The black markers indicate no measurable contamination (i.e., less than the minimum detectable activity [MDA]). The blue and red markers indicate possible and definite contamination, respectively. See Appendix A for a summary of the survey parameters.

Two field teams, using high-purity germanium (HPGe) gamma radiation detectors, conducted the measurements. At each measurement site, an HPGe detector was mounted on a 1-m (approximately-3 $\mathrm{ft}$ ) tripod, and data were collected for 900 seconds ( 15 minutes). The in situ method provides a gamma-ray spectrum that is an average of the radiation environment over the field of view of the detector. At a height of $1 \mathrm{~m}$, the field of view of the detector is a circular area having a radius of approximately $10 \mathrm{~m}$ ( $33 \mathrm{ft}$ ). For HPGe in situ measurements, the detector's field of view is generally defined as the area where 90 percent of the detected gamma rays having energies below 4,500

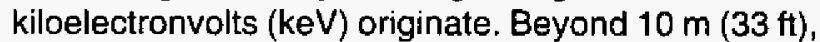
several factors including the air attenuation and solid angle subtended by the detector significantly decrease the contributions to the spectrum from lowenergy gamma rays. 


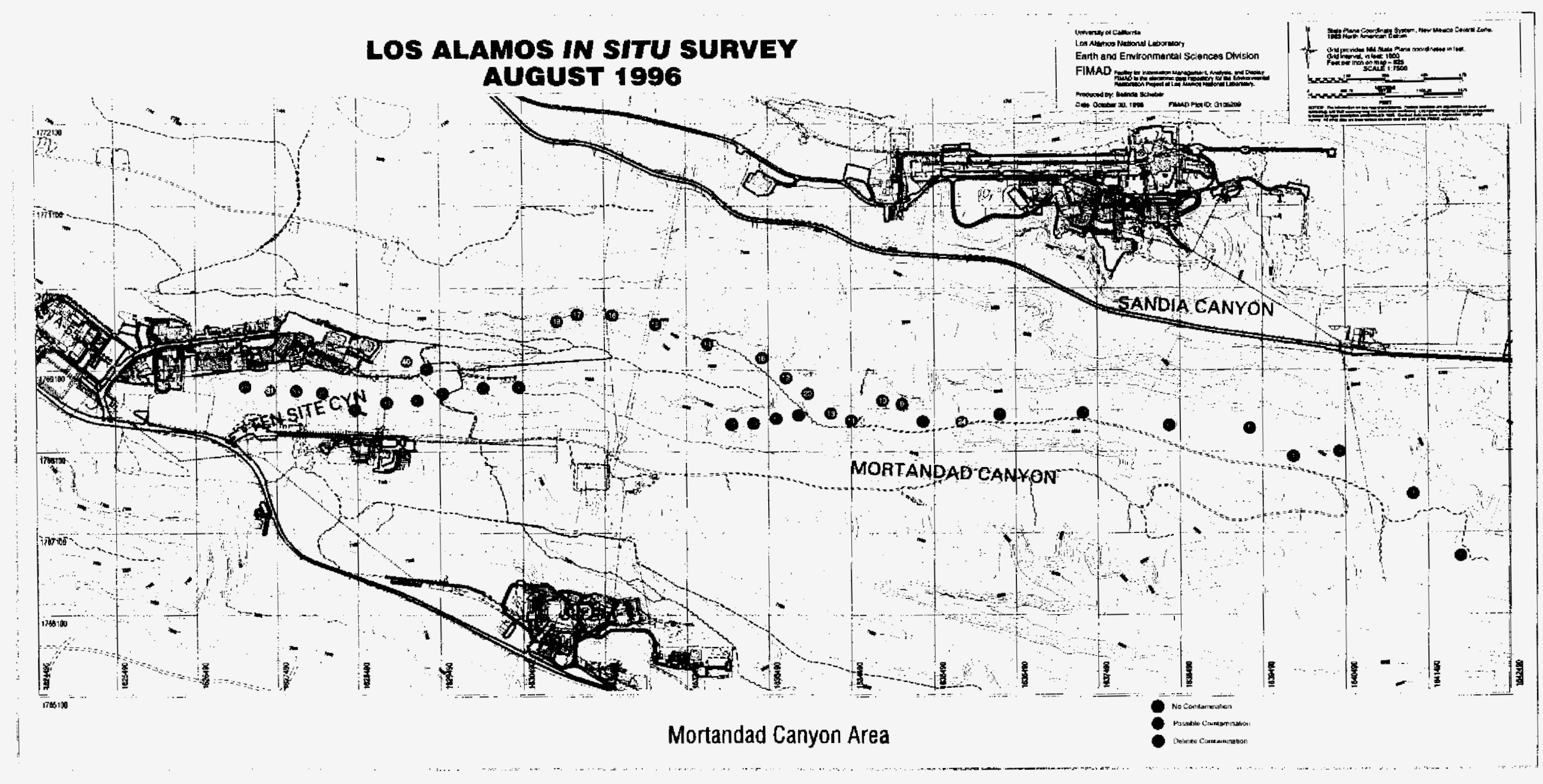

FIGURE 1. MAP OF MOHTANDAD ANO TEN SITE CANYONS SHOWING IHE LOCATIONS OF THE IN SITU MEASUREMENT SITES 


\section{LOS ALAMOS IN SITU SURVEY}

AUGUST 1996

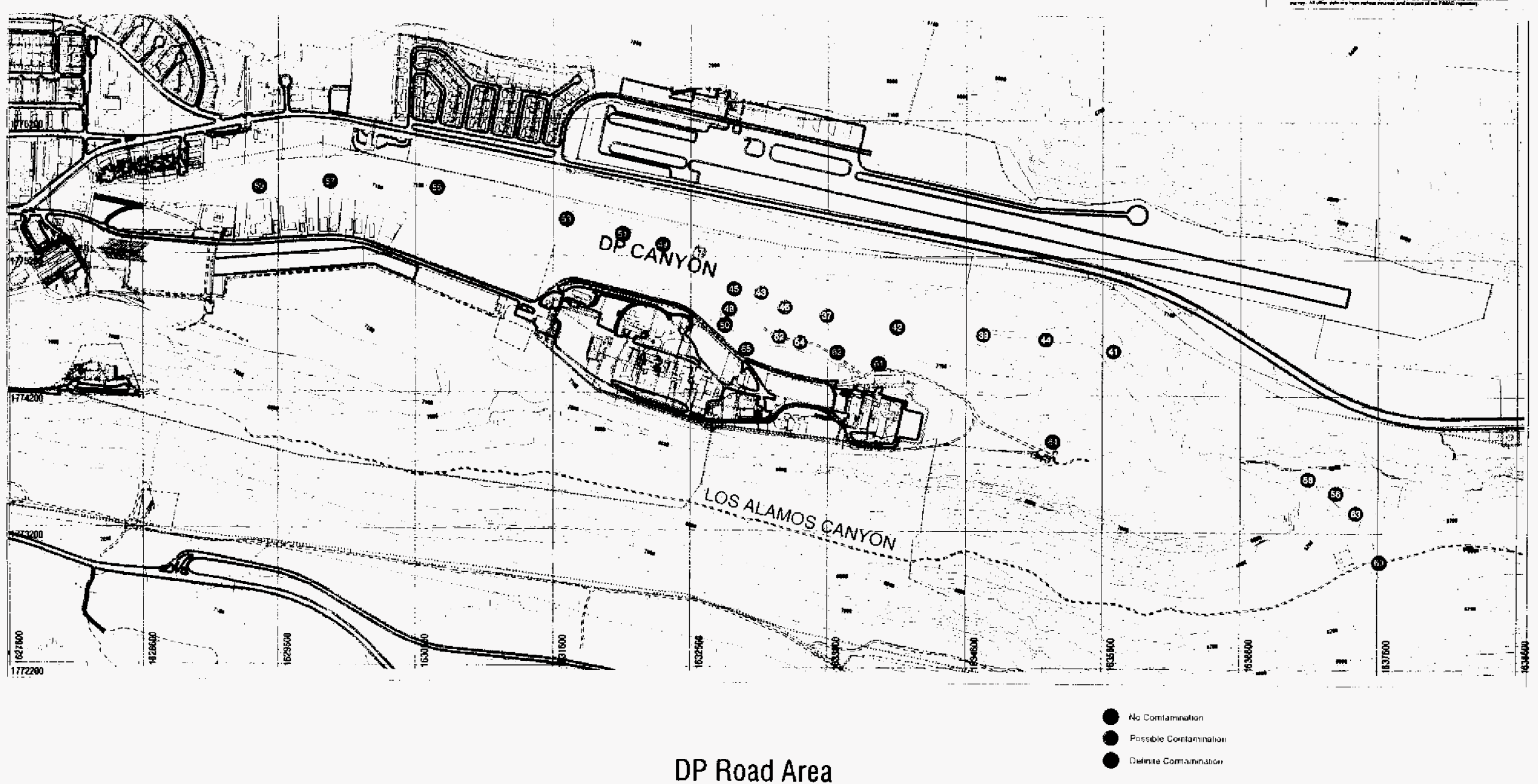


The area surveyed by a single in situ measurement is equivalent to the surface area contained in about 40 thousand soil samples -each sample measuring 4 in $(10 \mathrm{~cm})$ in diameter. After each measurement, the site was marked with a surveyor's pin flag with the site number and date, and the positional coordinates were recorded using a Global Positioning System (GPS) receiver. A total of 26, 12, and 27 in situ measurements were conducted in Mortandad, Ten Site, and DP Canyons, respectively.

\subsection{QUALITY CONTROL AND CALIBRATION}

A quality control procedure was implemented and employed throughout the survey to identify changes in the detector systems. The procedure involved a series of quality control measurements at the beginning and end of each day. The results of the measurements were compared daily to ensure the integrity of the detector systems. The quality control and calibration procedures meet the criteria specified by the American National Standards Institute, ANS! N42.14-1991.

Quality control measurements were conducted at a location designated as a "control point." The HPGe system was positioned on a 1-m tripod, and a 300 -second (5-minute) measurement of a radiation source traceable to the National Institute of Standards and Technology (NIST) was collected. The NISTtraceable composite radiation source consisted of a Lucite holder, measuring 1 in $(2.5 \mathrm{~cm})$ in diameter by 1 in long, with three metal capsules containing 5.9 microcuries $(\mu \mathrm{Ci})$ of americium-241 $\left({ }^{241} \mathrm{Am}\right), 14.3 \mu \mathrm{Ci}$ of cesium-137 $\left({ }^{137} \mathrm{Cs}\right)$, and $3.7 \mu \mathrm{Ci}$ of cobalt-60 $\left({ }^{60} \mathrm{Co}\right)$. A typical HPGe quality control data spectrum is presented in Figure 3 and shows the prominent gamma rays from the NIST composite source and the natural terrestrial background. The net photopeak counts from ${ }^{137} \mathrm{Cs}$ ( $661 \mathrm{keV}$ ) were recorded and used to monitor changes in the detector systems. During the two-week survey, the variation in the count rate for ${ }^{137} \mathrm{Cs}(661 \mathrm{keV})$ was found to be less than 2 percent for the two detector systems.

The NIST-traceable source was also used to determine the energy calibration of the HPGe system. The spectrum in Figure 3 shows gamma rays from ${ }^{241} \mathrm{Am}$ $(59.5 \mathrm{keV}),{ }^{137} \mathrm{Cs}(661.6 \mathrm{keV})$, and ${ }^{60} \mathrm{Co}(1,173.2$ and $1,332.5 \mathrm{keV}$ ) that provided an energy calibration over the primary energy region for man-made radionuclides. The energy calibration was determined by a linear least-squares fit of the peak reference gammaray energies and the peak centroid channel numbers. The energy calibration was used to identify gamma rays from man-made radionuclides in the spectral data obtained in the canyons.

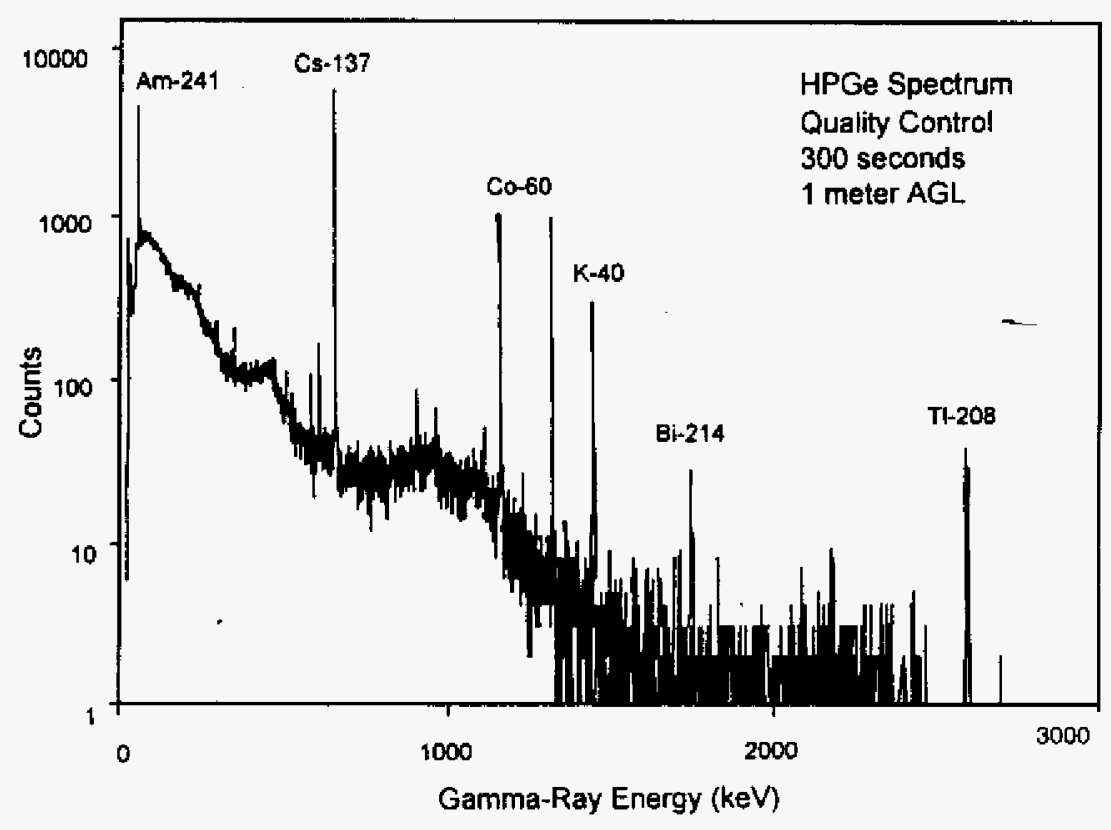

FIGURE 3. TYPICAL HPGE QUALITY CONTROL GAMMA-RAY SPECTRUM 


\subsection{IN SITU MEASUREMENT EQUIPMENT}

The in situ radiation detection system is shown in Figure 4. The system consists of an HPGe detector and a multichannel analyzer (MCA) on a 1-m tripod. Additional field equipment included a GPS receiver, a digital camera, and a laptop computer.

\subsection{HPGe Detector System}

Two EG\&G ORTEC HPGe coaxial detectors were used to measure the in situ gamma-ray spectra. The operational characteristics of the detectors are listed in Table 1. Each detector was coupled to a 1.5- $\ell$ liquid

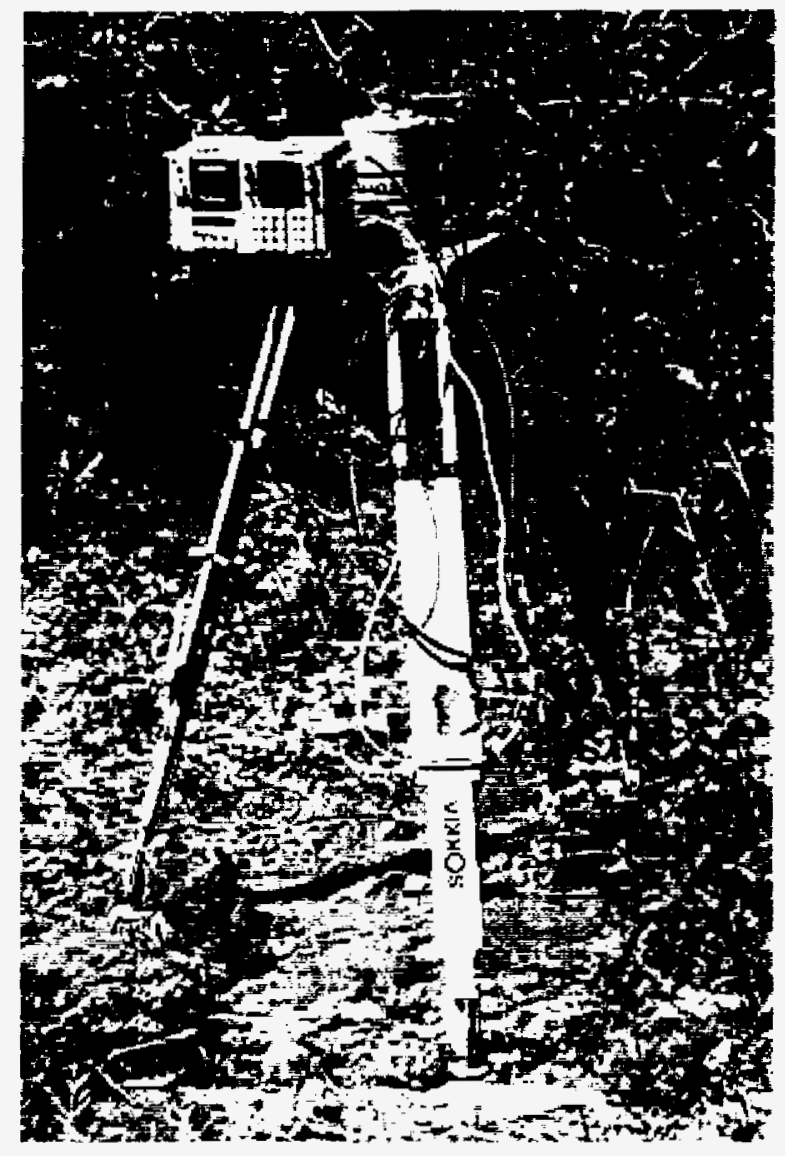

FIGURE 4. HPGE MEASUREMENT SYSTEM nitrogen cryostat that allowed for 12-hour continuous field operations. The detectors were n-type with an ultra-thin beryllium end-cap window for increased sensitivity to low-energy gamma rays. The tripods were fitted with a mounting plate to hold the detector in the vertical face-down position and an adjustable vise to hold the MCA. The tripod legs were adjusted so that the detector face was nominally $1 \mathrm{~m}$ from the surface of the ground.

The Davidson MCA is a portable, self-contained field unit that provides preamplifier and high-voltage power supplies; a spectroscopy amplifier; and a 4,096-channel, analog-to-digital converter (ADC). The MCA is programmable using an external keypad and a liquid crystal display (LCD). The unit contains a 2 -in $(5-\mathrm{cm})$ cathode-ray tube (CRT) for viewing the spectral data and a microcassette tape unit for recording the data. An internal battery provided an operational field life of eight hours.

\subsection{Global Positioning System}

Coordinates for the measurement locations were provided by the GPS receiver shown in Figure 5 . The system contains two receiver stations. The large dome antenna (left antenna) is the standard GPS receiver, and the smaller antenna (right antenna) is the differential correction receiver. The differential correction unit received data from the John Chance Corporation, which transmits differential corrections from a satellite in geosynchronous orbit. The differential corrections can be used to correct the standard GPS positional coordinates (typical accuracy of $\pm 100 \mathrm{~m}[300 \mathrm{ft}]$ ) to an accuracy of less than one meter. However, the differential lock was difficult to maintain in the narrow canyons. Therefore, the GPS coordinates reported for each site are the standard GPS coordinates accurate to $\pm 100 \mathrm{~m}(300 \mathrm{ft})$. The GPS coordinates are reported to the nearest tenth of an arc second. For reference, one second of latitude and longitude is approximately $31 \mathrm{~m}(101 \mathrm{ft})$ and $24 \mathrm{~m}(80 \mathrm{ft})$, respectively.

Table 1. HPGe Detector Characteristics

\begin{tabular}{c|c|c}
\hline Serial Number & Efficiency $^{\mathbf{a}}$ & FWHM $^{\mathbf{b}}$ \\
\hline ORTEC 34TN20879 & $101 \%$ & $2.7 \mathrm{keV}$ \\
ORTEC 34TN30888 & $90 \%$ & $2.5 \mathrm{keV}$ \\
\hline
\end{tabular}

Measured detection efficiency for ${ }^{60} \mathrm{Co}$ at $1,332 \mathrm{keV}$ versus a 3- $\times$ 3-in Nal(Tl) detector.

Deasured full width at half maximum for ${ }^{60} \mathrm{Co}$ at $1,332 \mathrm{keV}$. 


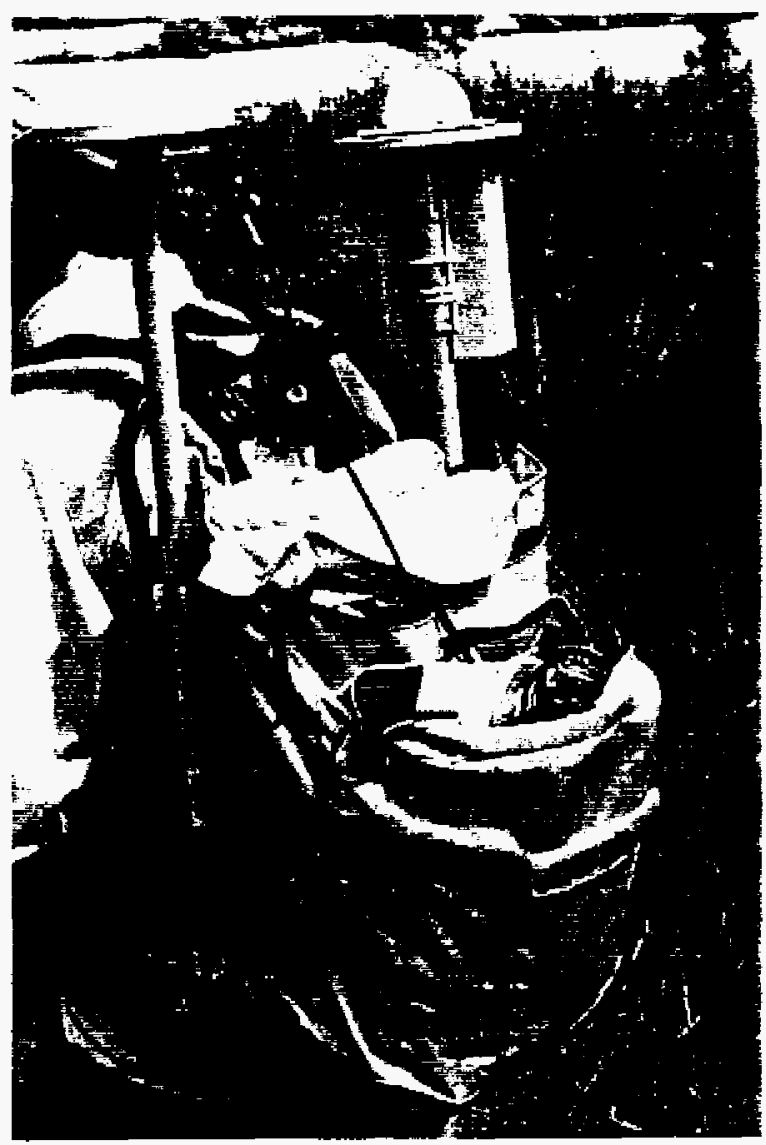

FIGURE 5, GLOBAL POSITIONING SYSTEM

\subsection{Data Analysis in the Field}

Initial screening and storage of the gamma spectral data in the field were conducted using a laptop computer. After each field measurement, the spectral data were downloaded to a laptop computer where the spectral data were screened for gamma rays from man-made radionuclides using "Gamma Data Reduction,"2 a commercial gamma-ray spectroscopic analysis software package. The analysis code was used to view the spectral data and conduct a peak search, peak-area calculation, and radionuclide identification before proceeding to the next measurement.

\subsection{ANGULAR EFFICIENCY CHARACTERIZATION}

Prior to the in silu survey, the HPGe detectors were characterized for angular efficiency at the RSL in Las Vegas, Nevada. For the characterization process, the detector was suspended in the vertical position. Directly beneath the detector was a semicircular arch that rotated a radiation point source at a constant $1-m$ distance from the detector face. A series of measurements were conducted with NIST-traceable point sources to include ${ }^{241} \mathrm{Am}(114 \mu \mathrm{Ci}),{ }^{137} \mathrm{Cs}(78.4 \mu \mathrm{Ci})$, and europium-152 (152Eu) $(61.6 \mu \mathrm{Ci})$. The sources were placed at 10-degree increments along the arch from 0 degrees (directly below the detector face) to 90 degrees during the characterization process. The radiation sources provided a range of gamma-ray energies from 32-1,408 keV. The net photopeak counts for the characteristic gamma rays from the NIST sources were extracted from the measured spectra and used to determine the conversion factors for photopeak count rate to soil activity concentration. The methodology used to derive the conversion factors is presented in Section 7.0.

\subsection{DERIVATION OF CONVERSION FACTORS}

A model is presented to derive the factors for converting detector photopeak count rates to soil activity concentration for in sifu measurements. The model is based on the methodology proposed by Beck $e t$ al. ${ }^{3}$ and Reiman. ${ }^{4}$ The conversion of photopeak-counting rate to activity is achieved by first determining the unscattered flux, $\phi$, from a point source of activity, $S_{0}$, and distance, $d_{a}$, in air as given in Equation 1:

$$
\phi=\frac{S_{0}}{4 \pi d_{a}^{2}} e^{-d_{a} / \lambda_{a}}
$$

where $\lambda_{a}$ is the mean free path of the gamma ray in air. The mean free path can also be expressed in terms of air attenuation as shown in the following equation:

$$
\phi=\frac{S_{0}}{4 \pi d_{a}^{2}} e^{-(\mu / \rho)_{a} \rho_{a} d_{a}}
$$

where $(\mu / \rho)_{a}$ represents the air mass attenuation coefficient and $p_{a}$ is the air density. A more general expression in Equation 3 can be derived for a point source embedded in the soil as follows:

$$
\phi=\frac{S_{0}}{4 \pi d^{2}} e^{-\left[(\mu / \rho)_{a} \rho_{a} d_{a}+(\mu / \rho)_{s} \rho_{s} d_{s}\right]}
$$


where the exponential term includes the mass attenuation coefficient and the density terms for both air and soil. The term $d=d_{a}+d_{s}$, where $d_{a}$ and $d_{s}$ are the distances in the air and soil, respectively, is the total distance that the gamma ray must travel to reach the detector. The unscattered gamma-ray flux from a source distributed in the soil can be integrated over all points in the soil as follows:

$N_{p}=\int_{0}^{\infty} \int_{0}^{\infty} \frac{S_{v} e^{-\left[(\mu / \rho)_{a} \rho_{a} d_{a}+\left(\mu / \rho_{s} \rho_{s} d_{s}\right]\right.}}{4 \pi r^{2}} 2 \pi r d r d z$

where $S_{0}$ in Equation 3 is replaced with $S_{y}$ representing the soil activity per unit volume. A schematic of the detector-soil interface geometry is shown in Figure 6.

For a detector system, the response to a monoenergetic gamma-ray flux from a point source situated normal to the detector surface is defined by the detectoreffective area $A_{0}$ and expressed as follows:

$$
A_{0}=\frac{N_{p}}{\phi}
$$

where $N_{p}$ is the net photopeak count rate in units of counts per second (cps). The angular response of the detector to a photon of energy $E_{\gamma}$ can be defined by $R\left(\theta, E_{\gamma}\right)$, and the effective area is defined as follows:

$$
A\left(\theta, E_{\gamma}\right)=A_{0} R\left(\theta, E_{\gamma}\right)
$$

The relative angular response function of a detector to an infinite, uniformly distributed source is often modeled as isotropic $[R(\theta)=1]$, cosine $\theta$, or a linear combination of the isotropic and cosine responses. The angular response function can also be determined experimentally as outlined in Section 6.0 by measuring the count rate from a point source at specific angles relative to the detector face.

Equation 4 assumes a source distribution that is uniformly distributed with depth and is useful in describing undistributed soil or soil that has undergone homogeneous mixing. Radioactive fallout that has been deposited on the surface will disperse into the soil over time, and the resulting distribution can be

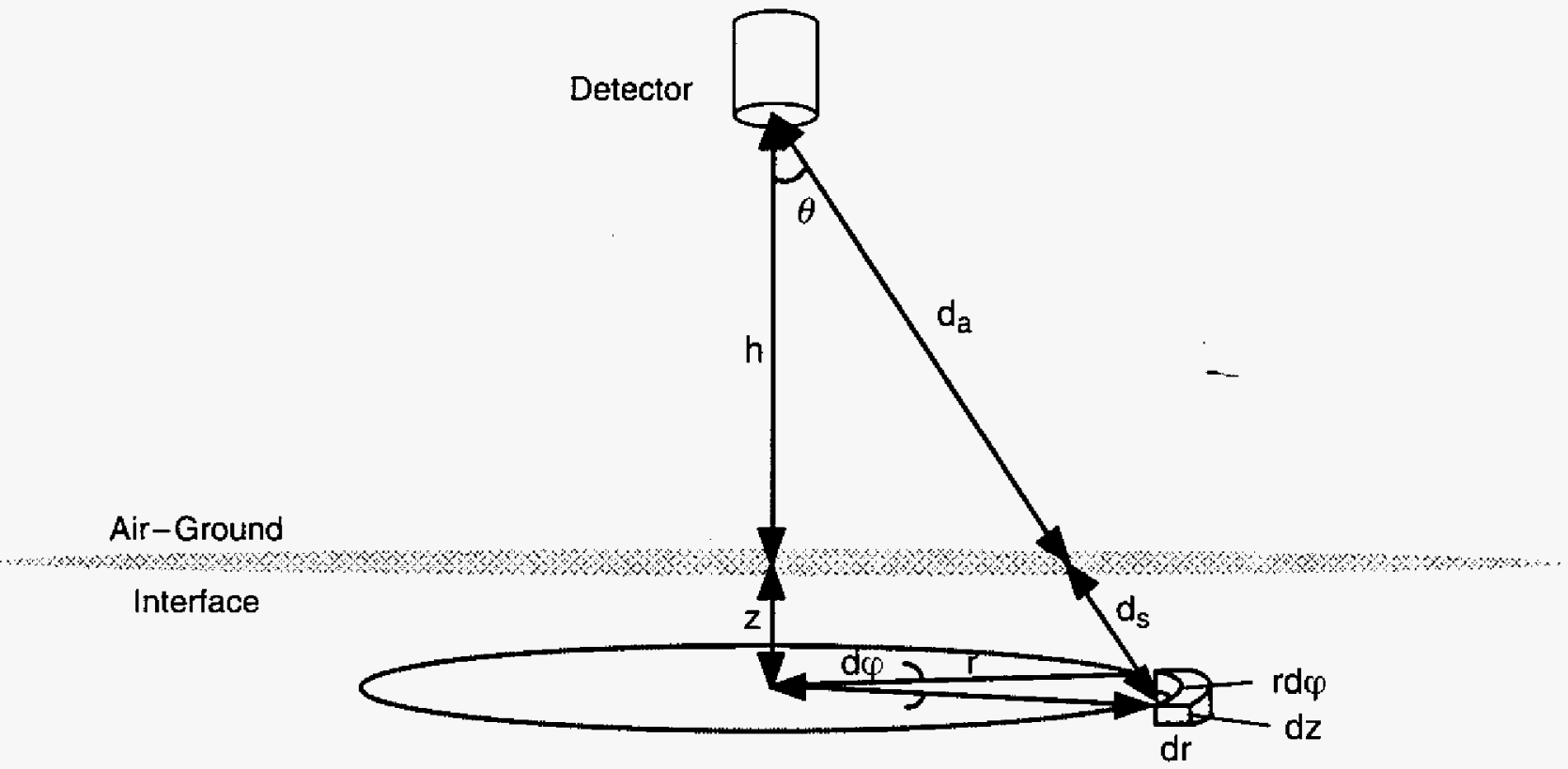

Source volume element

FIGURE 6. SCHEMATIC OF DETECTOR-SOIL INTERFACE GEOMETAV 
approximated by an exponential distribution given by the following equation:

$$
S_{1}=S_{1}^{0} e^{-\alpha_{s} z}
$$

where $S_{1}^{0}$ is the activity per unit volume at the surface, $z$ is the soil depth parameter, and $\alpha_{s}$ is the reciprocal of the relaxation length.

Beck ${ }^{4}$ derived the following relationship between the incident gamma-ray flux for a given gamma energy in a detector and the detector photopeak count rate for a radiation source distributed in the soil or on the soil surface.

$$
N_{p}=\frac{A_{0}}{2} \int_{0}^{\frac{\pi}{2}} \frac{S_{v}^{0} R(\theta) \tan \theta e^{-(\mu / \rho)_{a} \rho_{a} / t \sec \theta}}{a_{s}+(\mu / \rho\rangle_{s} \rho_{s} \sec \theta} d \theta
$$

where

$$
\begin{aligned}
S_{v^{\prime}}^{0}= & \text { source activity per unit volume at the } \\
& \text { surface }\left(\gamma / \mathrm{cm}^{3} \cdot \mathrm{s}\right) \\
A_{0}= & \text { detector-effective area at } 0 \text { degrees } \\
& \left(\mathrm{cm}^{2}\right) \\
R(\theta)= & \text { detector angular response function } \\
(\mu / \rho)_{a},(\mu / \rho)_{s}= & \text { air and soil mass attenuation } \\
& \text { coefficients }\left(\mathrm{cm}^{2} / \mathrm{g}\right) \\
\rho_{a}, \rho_{s}= & \text { air and soil densities ( } \left.\mathrm{g} / \mathrm{cm}^{3}\right) \\
\alpha_{5}= & \text { reciprocal of the relaxation length } \\
& \left(\mathrm{cm}^{-1}\right) \\
h= & \text { distance between soil surface and } \\
& \text { detector }(\mathrm{cm})
\end{aligned}
$$

It is common to convert the detector gamma-ray count rate to a soil activity concentration, expressed in units of picocuries per gram of soil. For a uniform soil activity concentration with depth, the following equation applies:

$$
S_{\rho}=\frac{S_{1}}{0.037 \rho_{s} \beta}
$$

where the parameter $\beta$ is the gamma-ray decay branching ratio, and the value of 0.037 is the number of disintegrations per second per picocurie.
The exponential soil activity distribution can be obtained by integrating Equation 7 over the soil depth parameter $z$ to obtain the average gamma-ray flux originating from the top $z \mathrm{~cm}$ of the soil.

$$
S_{\text {ave }}=\frac{1}{z} \int_{0}^{z} S_{1}^{0} e^{-\alpha_{s} z} d z=S_{1}^{0} \frac{1-e^{-a_{s z} z}}{a_{s z}}
$$

Then dividing by the soil density, the following expression is obtained:

$$
S_{\bar{p}}^{z}=S_{\nu}^{0}\left(\frac{1-e^{-a_{s} z}}{\rho_{s} z \alpha_{s}}\right)
$$

where $\alpha_{s}$ is the reciprocal of the relaxation length $\left(\mathrm{cm}^{-1}\right)$.

The relaxation length is used to define the distribution of activity in soil. The gamma-ray flux emitted from the soil, however, is a factor of both the relaxation length and the energy-dependent soil attenuation factor.

The two models presented thus far can be used to describe a range of soil activity distributions. The exponential soil activity distribution is used to model soil previously exposed to taliout that has since diffused into the soil. This model is most applicable to contamination from man-made radionuclides in the Los Alamos canyons. The uniform soil activity distribution is used to model the naturally occurring radionuclides in undisturbed soil or in contaminated soil that has undergone homogèneous mixing. For each model, the radioactive material is assumed to be uniformly distributed over an infinite plane with the activity variance only with depth.

The applicable model for the natural radionuclides is an infinite source in the horizontal direction with a uniform soil activity depth distribution. By using values for $\alpha_{s}$ and $z$ of $1 \times 10^{-6}$ and $5 \mathrm{~cm}$ ( 2 in), respectively, in the exponential depth distribution model, one can approximate the uniform activity depth distribution. Table 2 contains conversion factors for the natural radionuclides in picocuries per gram per counts per second ( $\mathrm{pCi} / \mathrm{g}$ per $\mathrm{cps}$ ) for the two HPGe detectors. 
Table 2. Conversion Factors for Natural Radionuclides (pCi/g per $\mathrm{cps}$ )

\begin{tabular}{c|c|c|c}
\hline Radionuclides & Gamma-Ray Energy & S/N 34TN20879a & S/N 34TN30888a \\
\hline${ }^{232} \mathrm{Th}\left({ }^{228} \mathrm{AC}\right)^{\mathrm{b}}$ & $911 \mathrm{keV}$ & 0.9 & 1.0 \\
${ }^{40 \mathrm{~K}}$ & $1,460 \mathrm{keV}$ & 2.6 & 3.0 \\
${ }^{238} \mathrm{U}\left({ }^{214} \mathrm{Bi}\right)^{\mathrm{C}}$ & $1,764 \mathrm{keV}$ & 1.8 & 2.2 \\
\hline
\end{tabular}

a HPGe detector serial numbers.

b Actinium-228 is a member of the decay chain that can be used to infer ${ }^{232} \mathrm{Th}$ activity.

c Bismuth-214 is a member of the decay chain that can be used to infer ${ }^{238} \mathrm{U}$ activity.

The conversion factors derived in Table 2 are for sources of infinite areal extent. For sources of finite extent, conversion factors can be calculated ${ }^{5}$ by numerical integration of Equation 4 (circular sources) or by pertorming the coordinate transformation $d x^{\prime} d y^{\prime}$ $=2 \pi x d x$ and then integrating numerically (rectangular sources). The conversion factors for the photopeak count rate to picocuries per gram are presented in Tables 3 and 4 for (a) uniform soil activity depth distributions and (b) exponential soil activity depth distributions for the man-made radionuclides ${ }^{241} \mathrm{Am}$, ${ }^{137} \mathrm{Cs}$, and ${ }^{60} \mathrm{Co}$ for the two HPGe detectors, respectively. The conversion factors are for $1 \mathrm{~m}$ above ground level (AGL) with a soil density of $1.5 \mathrm{~g} / \mathrm{cm}^{3}$.

The three radionuclides presented in the tables were the only man-made radiological contaminants detected in the canyons. To determine the soil activity concentrations, the net photopeak count rate in counts per second is multiplied by the appropriate conversion factor for the applicable streambed geometry. The conversion factors are calculated for radially symmetric distributions with source radii ranging from $R=1$ to $30 \mathrm{~m}$ ( 3 to $100 \mathrm{ft}$ ) and for rectangular distributions with source extensions ranging from 6 by $2 \mathrm{~m}$ ( 20 by $7 \mathrm{ft}$ ) to 60 by $20 \mathrm{~m}$ ( 200 by $66 \mathrm{ft}$ ).

The value of the relaxation length used in the exponential depth distribution model was selected to be $0.33 \mathrm{~cm}^{-1}$. The $\alpha^{-1}$ value of $3 \mathrm{~cm}(1.2 \mathrm{in})$ has been used to model ${ }^{6}$ surface-deposited radionuclides that have diffused into the soil over extended periods. The depth parameter $z$ used to derive the conversion factors was based on the maximum attenuation length for the gamma ray of interest. Assuming. that the radionuclides are concentrated in the first $3 \mathrm{~cm}$ of soil, low-energy gamma rays such as the 59-keV gamma from ${ }^{241} \mathrm{Am}$ will be significantly attenuated by the soil whereas high-energy gamma rays such as the $1,332-k e V$ gamma from ${ }^{60} \mathrm{Co}$ will undergo only minimal attenuation.

Table 3. Conversion Factors for Radionuclide Distributions (HPGe S/N 34TN30888)

A. Uniform Depth Distributions (pCi/g per cps)

\begin{tabular}{c|c|c|c|c|c|c|c|c|c|c}
\hline Isotope & $\mathbf{R}=\mathbf{3 0}$ & $\mathbf{R = 1 0}$ & $\mathbf{R = 3}$ & $\mathbf{R = 1}$ & $\mathbf{6 0} \times \mathbf{2 0}$ & $\mathbf{6 0} \times \mathbf{6}$ & $\mathbf{6 0} \times \mathbf{2}$ & $\mathbf{2 0} \times \mathbf{6}$ & $\mathbf{2 0} \times \mathbf{2}$ & $\mathbf{6} \times \mathbf{2}$ \\
\hline${ }^{241} \mathrm{Am}$ & 1.06 & 1.12 & 1.46 & 3.68 & 1.1 & 1.27 & 2.07 & 1.28 & 2.08 & 2.20 \\
${ }^{137} \mathrm{Cs}$ & 0.38 & 0.40 & 0.55 & 1.42 & 0.39 & 0.46 & 0.777 & 0.47 & 0.78 & 0.83 \\
${ }^{60} \mathrm{Co}$ & 0.37 & 0.39 & 0.53 & 1.40 & 0.38 & 0.45 & 0.759 & 0.46 & 0.76 & 0.81 \\
\hline
\end{tabular}

B. Exponential Depth Distributions (pCi/g per cps)

\begin{tabular}{c|c|c|c|c|c|c|c|c|c|c}
\hline Isotope & $\mathbf{R = 3 0}$ & $\mathbf{R = 1 0}$ & $\mathbf{R = 3}$ & $\mathbf{R = 1}$ & $\mathbf{6 0} \times \mathbf{2 0}$ & $\mathbf{6 0} \times \mathbf{6}$ & $\mathbf{6 0} \times \mathbf{2}$ & $\mathbf{2 0} \times \mathbf{6}$ & $\mathbf{2 0} \times \mathbf{2}$ & $\mathbf{6} \times \mathbf{2}$ \\
\hline${ }^{241} \mathrm{Am}$ & 1.46 & $\mathbf{1 . 5 7}$ & 2.17 & 6.07 & 1.52 & 1.82 & 3.15 & 1.84 & $\mathbf{3 . 1 7}$ & 3.41 \\
${ }^{137} \mathrm{Cs}$ & 0.77 & $\mathbf{0 . 8 7}$ & 1.37 & 4.22 & 0.82 & 1.07 & 1.98 & 1.09 & $\mathbf{2 . 0 0}$ & 2.24 \\
${ }^{60} \mathrm{Co}$ & 0.87 & $\mathbf{1 . 0 1}$ & 1.62 & 5.14 & 0.95 & 1.25 & 2.37 & 1.27 & $\mathbf{2 . 3 9}$ & 2.70 \\
\hline
\end{tabular}

(1) The column headings " $\mathrm{R}=$ " denote the radius in meters of the isolopic distribution.

(2) The column headings " $-x^{n}$ " denote the rectangular area in meters of the isotopic distribution. 
Table 4. Conversion Factors for Radionuclide Distributions (HPGe S/N 34TN20879)

A. Uniform Depth Distributions (pCi/g per cps)

\begin{tabular}{c|c|c|c|c|c|c|c|c|c|c}
\hline Isotope & $\mathbf{R = 3 0}$ & $\mathbf{R = 1 0}$ & $\mathbf{R = 3}$ & $\mathbf{R = 1}$ & $\mathbf{6 0} \times \mathbf{2 0}$ & $\mathbf{6 0} \times \mathbf{6}$ & $\mathbf{6 0} \times \mathbf{2}$ & $\mathbf{2 0} \times \mathbf{6}$ & $\mathbf{2 0} \times \mathbf{2}$ & $\mathbf{6} \times \mathbf{2}$ \\
\hline${ }^{241} \mathrm{Am}$ & 1.00 & 1.05 & 1.37 & 3.44 & 1.03 & 1.19 & 1.93 & 1.21 & 1.95 & 2.05 \\
${ }^{137} \mathrm{Cs}$ & 0.33 & 0.36 & 0.48 & 1.26 & 0.35 & 0.41 & 0.69 & 0.42 & 0.70 & 0.74 \\
${ }^{60} \mathrm{Co}$ & 0.32 & 0.35 & 0.47 & 1.26 & 0.34 & 0.40 & 0.68 & 0.41 & 0.69 & 0.73 \\
\hline
\end{tabular}

B. Exponential Depth Distributions (pCi/g per cps)

\begin{tabular}{c|c|c|c|c|c|c|c|c|c|c}
\hline Isotope & $\mathbf{R = 3 0}$ & $\mathbf{R = 1 0}$ & $\mathbf{R = 3}$ & $\mathbf{R = 1}$ & $\mathbf{6 0} \times \mathbf{2 0}$ & $\mathbf{6 0} \times \mathbf{6}$ & $\mathbf{6 0} \times \mathbf{2}$ & $\mathbf{2 0} \times \mathbf{6}$ & $\mathbf{2 0} \times \mathbf{2}$ & $\mathbf{6} \times \mathbf{2}$ \\
\hline${ }^{241} \mathrm{Am}$ & 1.38 & $\mathbf{1 . 4 7}$ & 2.04 & 5.68 & 1.43 & 1.72 & 2.94 & 1.73 & $\mathbf{2 . 9 7}$ & 3.18 \\
${ }^{137} \mathrm{Cs}$ & 0.68 & $\mathbf{0 . 7 7}$ & 1.21 & 3.75 & 0.72 & 0.94 & 1.75 & 0.96 & $\mathbf{1 . 7 7}$ & 1.98 \\
${ }^{60} \mathrm{Co}$ & 0.78 & 0.90 & 1.47 & 4.63 & 0.85 & 1.13 & 2.13 & 1.15 & $\mathbf{2 . 1 5}$ & 2.44 \\
\hline
\end{tabular}

(1) The column headings " $R={ }_{-}$" denote the radius in meters of the isotopic distribution.

(2) The column headings " $x_{-}$" denote the rectangular area in meters of the isotopic distribution.

A review of the conversion factors in Tables 3 and 4 indicates that the differences between the infinite (approximated by the $R=30-\mathrm{m}$ [100-ft] conversion factor) and finite source distributions are largest for the exponential distributions and smallest for uniform soil distributions. As an example, the relative conversion factors for a source having an area of 60 by 2 $\mathrm{m}(200$ by $6 \mathrm{ft})$ (an approximation to a straight streambed) are approximately 2 for a uniform soil distribution and 2.2-2.7 for an exponential soil distribution. The magnitude of these correction factors indicates that the terrain of the measurement site must be taken into account to provide the most accurate estimates of soil activity distributions.

\subsection{DATA ANALYSIS PROCEDURES}

At the completion of the in situ survey, the spectral data were archived and analyzed using gamma-ray spectroscopic analysis software. The quality control spectrum acquired at the beginning of each day was used to calibrate the energy scale for spectral analysis. The gamma-ray spectra were analyzed by fitting a normalized empirical Gaussian distribution function to the photopeaks of interest and subtracting the gamma-ray background and Compton continuum. The statistical uncertainty in the photopeak area attributed to the peak-fitting routine was typically less than 5 percent. The measured photopeak energies were compared to reference energies in a radionuclide library, and the corresponding radionuclides were identified. All gamma rays were identified as originating from either natural radionuclides or the three manmade radionuclides previously mentioned.

\subsection{In Situ Measurement of Natural Terrestrial Radiation}

A typical spectrum of natural terrestrial in situ garnma-ray energy is shown in Figure 7. The natural terrestrial radionuclides and their prominent gamma rays that can be detected by the in situ method are listed in Table 5. The environment of natural terrestrial radiation contains many gamma rays that primarily originate from the decay chains of uranium-238 (238U) and thorium-232 (232 $\mathrm{Th})$ and from potassium-40 $\left({ }^{40} \mathrm{~K}\right)$. The ${ }^{232} \mathrm{Th}$ radionuclide is in secular equilibrium with its decay progeny actinium-228 $\left({ }^{228} \mathrm{Ac}\right)$, and thus the $911-\mathrm{keV}$ gamma ray from ${ }^{228} \mathrm{Ac}$ can be used to infer the concentration of ${ }^{232} \mathrm{Th}$. A similar relationship exists for ${ }^{238} U$ that is in seeular equilibrium with its decay progeny bismuth-214 $\left({ }^{214} \mathrm{Bi}\right)$, and thus the 1,764-keV gamma ray from ${ }^{214} \mathrm{Bi}$ can be used to infer ${ }^{238} \mathrm{U}$ concentration. Although not attributable to natural terrestrial radiation, ${ }^{137} \mathrm{Cs}$ is also present in the in situ spectrum. Detectable levels of ${ }^{137} \mathrm{Cs}$ at the laboratory could arise either from worldwide fallout from atmospheric nuclear weapons tests or releases from the laboratory.

\subsection{In Situ Measurement of Man-Made Radionuclides}

Presented in Figure 8 is an in situ measurement spectrum acquired at Site 19 in Mortandad Canyon. The 


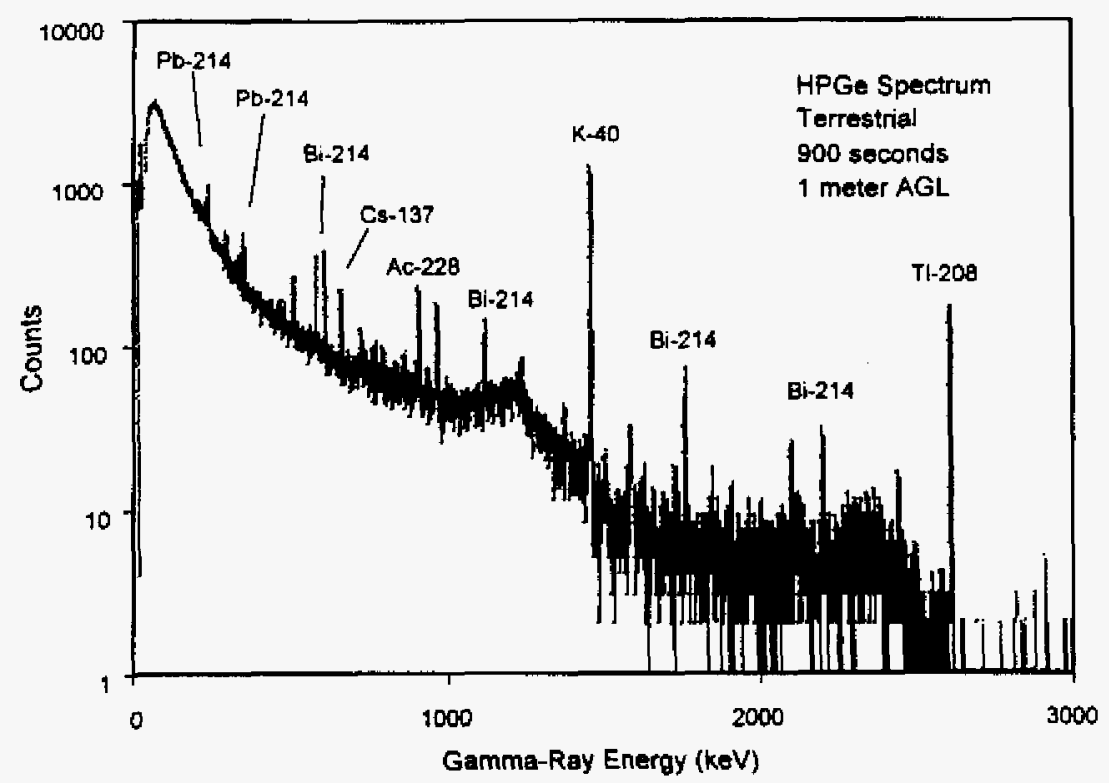

FIGUAE 7. TYPICAL HPGE NATURAL TERAESTRIAL GAMMA-RAY SPECTRUM

spectrum was measured in a streambed $6 \mathrm{ft}(2 \mathrm{~m})$ wide by $4 \mathrm{ft}(1.2 \mathrm{~m})$ deep located at the western end of the canyon about $1 \mathrm{mi}(1.6 \mathrm{~km})$ from the release point for waste water at the TA-35 complex. The spectrum clearly indicates the presence of the man-made radionuclides ${ }^{241} \mathrm{Am}(59 \mathrm{keV}),{ }^{137} \mathrm{Cs}(661 \mathrm{keV})$, and ${ }^{60} \mathrm{Co}(1,173$ and $1,332 \mathrm{keV})$.

Presented in Table 6 are the MDAs for the ${ }^{241} \mathrm{Am}$, ${ }^{137} \mathrm{Cs}$, and ${ }^{60} \mathrm{Co}$ radionuclides. The MDA represents the amount of activity of a radionuclide that must be present before it can be detected with any certainty. The MDA is generally defined at the $3 \sigma$ statistical level, where $\sigma$ is the standard deviation of the background counts in the photopeak window.
The MDA value for a detector is a function of the gamma-ray energy, the soil-matrix distribution, the detector-source geometry, the photopeak background count rate, and the analysis methodology. The MDA for ${ }^{241} \mathrm{Am}$ was determined to be approximately $10 \mathrm{pCi} / \mathrm{g}$. It should be noted that ${ }^{241} \mathrm{Am}$ was only detected in the presence of elevated levels of ${ }^{137} \mathrm{Cs}$ and ${ }^{60} \mathrm{Co}$, both emitting high-energy gamma rays that contribute to the low-energy Compton continuum. As a result, the detection sensitivity for ${ }^{241} \mathrm{Am}$ is greatly reduced. The MDA for ${ }^{241} \mathrm{Am}$ would be significantlylower if there was no interference from the other manmade radionuclides.

Table 5. Natural Terrestrial Radiation in HPGe In Situ Measurements

\begin{tabular}{|c|c|c|}
\hline Radionuclides & Decay Products & $\begin{array}{c}\text { Detected Gamma Ënergies } \\
\text { (keV) }\end{array}$ \\
\hline $238 \mathrm{U}$ & $\begin{array}{l}214 \mathrm{~Pb} \\
214 \mathrm{Bi}\end{array}$ & $\begin{array}{l}242 ; 295 ; 352 \\
609 ; 1,120 ; 1,764 ; 2,204\end{array}$ \\
\hline${ }^{232} \mathrm{Th}$ & $\begin{array}{l}208 \mathrm{Tl} \\
228 \mathrm{Ac} \\
212 \mathrm{~Pb} \\
224 \mathrm{Ra}\end{array}$ & $\begin{array}{l}511 ; 583 ; 2,103 ; 2,614 \\
338 ; 911 ; 965 / 969 \\
239 \\
241\end{array}$ \\
\hline $40 \mathrm{~K}$ & & 1,460 \\
\hline${ }^{137} \mathrm{Cs}^{\mathrm{a}}$ & & 661 \\
\hline
\end{tabular}

a Attributed to worldwide fallout. 


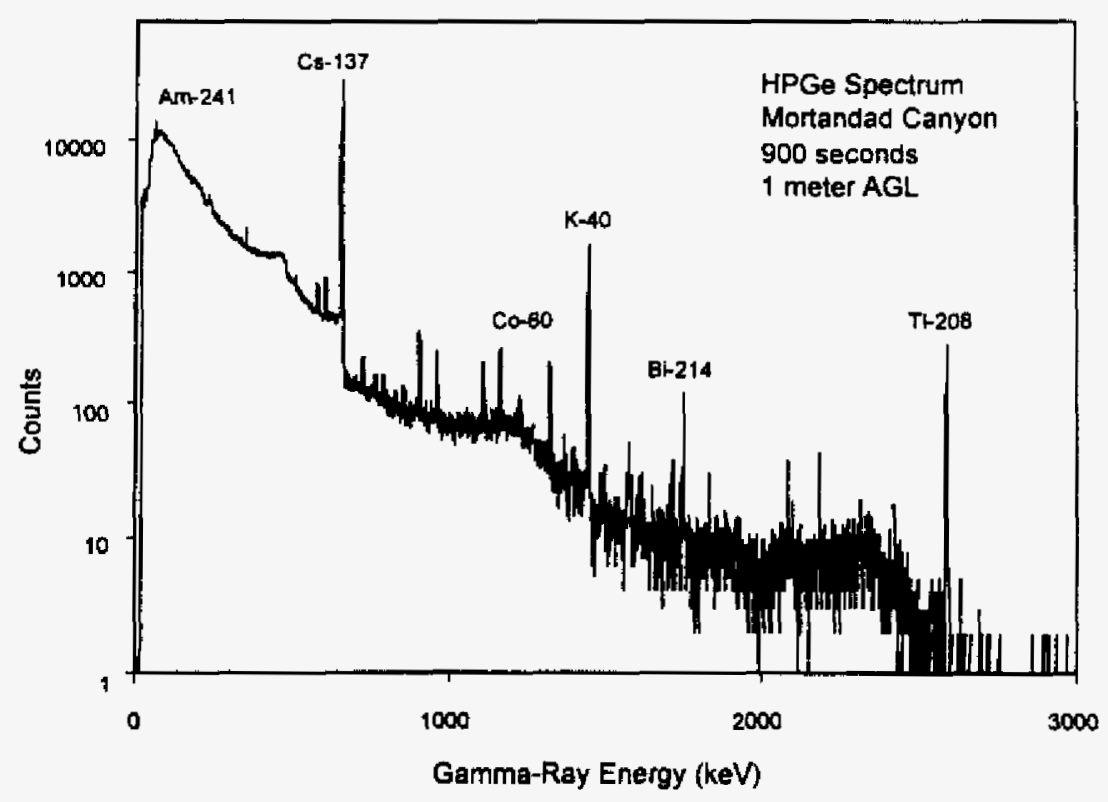

FIGURE 8. TYPICAL HPGE GAMMA-RAY SPECTRUM FROM MORTANDAD CANYON (SITE 19). Thissite exhlbited highlevels ofall three man-maderadionuclides.

\subsection{DISCUSSION OF DATA}

The results of the in situ surveys in Mortandad, Ten Site, and DP Canyons are presented in Tables 7-9. The tables contain the site number, the GPS position coordinates in latitude and longitude, and the net photopeak count rates. The estimated soil activity concentrations for the man-made radionuclides are denoted in parenthesis and are given in units of picocuries per gram. The tables contain data for the manmade radionuclides, which include ${ }^{241} \mathrm{Am}(59 \mathrm{keV})$, ${ }^{137} \mathrm{Cs}(661 \mathrm{keV})$, and ${ }^{60} \mathrm{Co}(1,332 \mathrm{keV})$, and the natural radionuclides, which include ${ }^{40} \mathrm{~K}(1,460 \mathrm{keV})$, ${ }^{232} \mathrm{Th}(911 \mathrm{keV})$, and ${ }^{238} \mathrm{U}(1,764 \mathrm{keV})$, for each site measurement. The symbol "< MDA" denotes "less than the minimum detectable activity" and is attributable to a net photopeak area that is less than the $3 \sigma$ MDA value.
The net photopeak count rates for the man-made radionuclides have been converted to picocuries per gram using the conversion factors (denoted in bold print) from the exponential depth distribution model with finite-extended source size in Tables 3 and 4. For the narrow, trench-like streambeds, it is assumed that the man-made radionuclides are embedded in the streambed. The model that best approximates this geometry is a rectangular source measuring 20 by $2 \mathrm{~m}$ ( 65 by $6 \mathrm{ft}$ ) long. For the larger, nearly flat watercollection areas surrounded by berms, the model that best approximates this geometry is a circular area having a radius $(R)$ of $10 \mathrm{~m}(33 \mathrm{ft})$.

For the natural radionuclides, the data (derived from conversion factors in Table 2 for infinite source distributions) show only small variations in count rates for the ${ }^{238} \mathrm{U},{ }^{232} \mathrm{Th}$, and ${ }^{40} \mathrm{~K}$ radionuclides despite measurements taken in a variety of terrains ranging from

Table 6. Man-Made Radionuclides and MDAs (pCi/g)

\begin{tabular}{c|c|c|c}
\hline Radionuclides & Gamma-Ray Energy (keV) & S/N 34TN20879a & S/N 34TN30888a \\
\hline${ }^{241} \mathrm{Am}$ & 59.5 & $\sim 10$ & -10 \\
${ }^{137} \mathrm{Cs}$ & 661.6 & 0.4 & 0.4 \\
${ }^{60} \mathrm{Co}$ & $1,332.5$ & 0.3 & 0.3 \\
\hline
\end{tabular}

a HPGe detector serial numbers. 
Table 7. Soil Activity Concentration for In Situ Data at Mortandad Canyon

\begin{tabular}{|c|c|c|c|c|c|c|c|c|}
\hline \multirow{2}{*}{$\begin{array}{l}\text { Site } \\
\text { No. }\end{array}$} & \multicolumn{2}{|c|}{ GPS Position } & \multicolumn{6}{|c|}{$\begin{array}{l}\text { Photopeak Counts per Second } \\
\text { (Soil Activity Concentration-pCi/g) }\end{array}$} \\
\hline & Latitude (N) & Longitude (W) & ${ }^{241} \mathrm{Am}$ & ${ }^{137} \mathrm{Cs}$ & ${ }^{60} \mathrm{Co}$ & ${ }^{40} \mathrm{~K}$ & ${ }^{232} \mathrm{Th}$ & 238U \\
\hline 1 & $35^{\circ} 51^{\prime} 20.8^{\prime \prime}$ & $106^{\circ} 14^{\prime} 44.2^{\prime \prime}$ & $<M D A$ & $0.9(0.8)^{\mathrm{a}}$ & $<M D A$ & 8.2 & 1.2 & 0.6 \\
\hline 2 & $35^{\circ} 51^{\prime} 26.5^{\prime \prime}$ & $106^{\circ} 14^{\prime} 46.5^{\prime \prime}$ & $<\mathrm{MDA}$ & $1.2(0.9)^{\mathrm{a}}$ & $<\mathrm{MDA}$ & 10.1 & 1.3 & 0.6 \\
\hline 3 & $35^{\circ} 51^{\prime} 32.5^{\prime \prime}$ & $106^{\circ} 14^{\prime} 55.9^{\prime \prime}$ & $<$ MDA & $0.9(0.8)^{\mathrm{a}}$ & $<M D A$ & 8.8 & 0.9 & 0.5 \\
\hline 4 & $35^{\circ} 51^{\prime} 35.8^{\prime \prime}$ & $106^{\circ} 15^{\prime} 08.1^{\prime \prime}$ & $<M D A$ & $1.5(1.1)^{\mathrm{a}}$ & $<M D A$ & 10.2 & 1.0 & 0.5 \\
\hline 5 & $35^{\circ} 51^{\prime} 37.9^{\prime \prime}$ & $106^{\circ} 15^{\prime} 18.0^{\prime \prime}$ & $<\mathrm{MDA}$ & $2.0(1.7)^{\mathrm{a}}$ & $<\mathrm{MDA}$ & 8.5 & 1.6 & 0.7 \\
\hline 6 & $35^{\circ} 51^{\prime} 40.6^{\prime \prime}$ & $106^{\circ} 15^{\prime} 28.1^{\prime \prime}$ & $<\mathrm{MDA}$ & $1.5(1.1)^{\mathrm{a}}$ & $<M D A$ & 11.4 & 1.9 & 0.9 \\
\hline 7 & $35^{\circ} 51^{\prime} 38.6^{\prime \prime}$ & $106^{\circ} 15^{\prime} 40.6^{\prime \prime}$ & $<M D A$ & $0.8(0.7)^{\mathrm{a}}$ & $<M D A$ & 9.3 & 0.9 & 0.4 \\
\hline 8 & $35^{\circ} 51^{\prime} 42.2^{\prime \prime}$ & $106^{\circ} 15^{\prime} 55.5^{\prime \prime}$ & $<M D A$ & $1.8(1.4)^{\mathrm{a}}$ & $<M D A$ & 11.2 & 1.6 & 0.8 \\
\hline 9 & $35^{\circ} 51^{\prime} 39.5^{\prime \prime}$ & $106^{\circ} 16^{\prime} 05.2^{\prime \prime}$ & $10.4(16.3)^{\mathrm{a}}$ & $48.0(41.6)^{\mathrm{a}}$ & $0.4(0.4)^{\mathrm{a}}$ & 10.6 & 1.4 & 0.6 \\
\hline 10 & $35^{\circ} 51^{\prime} 39.8^{\prime \prime}$ & $106^{\circ} 16^{\prime} 07.6^{\prime \prime}$ & $40.8(59.9)^{\mathrm{a}}$ & $85.3(65.4)^{\mathrm{a}}$ & $0.8(0.7)^{\mathrm{a}}$ & 11.2 & 1.8 & 0.7 \\
\hline 11 & $35^{\circ} 51^{\prime} 36.8^{\prime \prime}$ & $106^{\circ} 16^{\prime} 11.3^{\prime \prime}$ & $56.8(89.1)^{\mathrm{a}}$ & $91.9(79.7)^{\mathrm{a}}$ & $1.0(1.0)^{\mathrm{a}}$ & 9.3 & 1.6 & 0.7 \\
\hline 12 & $35^{\circ} 51^{\prime} 46.7^{\prime \prime}$ & $106^{\circ} 16^{\prime} 26.1^{\prime \prime}$ & $52.2(155.0)^{b}$ & $97.6(172.7)^{b}$ & $1.0(2.1)^{\mathrm{b}}$ & 11.4 & 1.6 & 0.7 \\
\hline 13 & $35^{\circ} 51^{\prime} 42.5^{\prime \prime}$ & $106^{\circ} 16^{\prime} 13.6^{\prime \prime}$ & $15.7(49.7)^{\mathrm{b}}$ & $98.5(197.0)^{b}$ & $0.5(1.2)^{\mathrm{b}}$ & 8.5 & 1.2 & 0.6 \\
\hline 14 & $35^{\circ} 51^{\prime} 47.7^{\prime \prime}$ & $106^{\circ} 16^{\prime} 34.8^{\prime \prime}$ & $13.5(40.0)^{b}$ & $120.9(213.9)^{b}$ & $0.8(1.7)^{\mathrm{b}}$ & 10.6 & 1.2 & 0.6 \\
\hline 15 & $35^{\circ} 51^{\prime} 49.4^{\prime \prime}$ & $106^{\circ} 16^{\prime} 42.0^{\prime \prime}$ & $16.7(52.9)^{b}$ & $92.9(185.8)^{b}$ & $0.8(1.9)^{\mathrm{b}}$ & 10.1 & 1.6 & 0.7 \\
\hline 16 & $35^{\circ} 51^{\prime} 49.8^{\prime \prime}$ & $106^{\circ} 16^{\prime} 43.9^{\prime \prime}$ & $17.1(50.7)^{\mathrm{b}}$ & $82.8(146.5)^{b}$ & $0.9(1.9)^{b}$ & 11.1 & 1.8 & 0.7 \\
\hline 17 & $35^{\circ} 51^{\prime} 49.3^{\prime \prime}$ & $106^{\circ} 16^{\prime} 50.7^{\prime \prime}$ & $63.2(200.3)^{b}$ & $108.5(217.0)^{b}$ & $0.8(1.9)^{\mathrm{b}}$ & 9.9 & 1.6 & 0.7 \\
\hline 18 & $35^{\circ} 51^{\prime} 47.1^{\prime \prime}$ & $106^{\circ} 16^{\prime} 31.1^{\prime \prime}$ & $32.5(96.5)^{\mathrm{b}}$ & $129.0(228.3)^{b}$ & $1.2(2.6)^{\mathrm{b}}$ & 10.2 & 1.3 & 0.5 \\
\hline 19 & $35^{\circ} 51^{\prime} 46.1^{\prime \prime}$ & $106^{\circ} 16^{\prime} 51.9^{\prime \prime}$ & $48.8(154.6)^{b}$ & $163.9(327.8)^{b}$ & $0.9(2.1)^{\mathrm{b}}$ & 10.5 & 1.6 & 0.7 \\
\hline 20 & $35^{\circ} 51^{\prime} 41.2^{\prime \prime}$ & $106^{\circ} 16^{\prime} 17.9^{\prime \prime}$ & $23.3(69.2)^{b}$ & $61.7(109.2)^{b}$ & $0.7(1.5)^{b}$ & 10.4 & 1.3 & 0.5 \\
\hline 21 & $35^{\circ} 51^{\prime} 37.5^{\prime \prime}$ & $106^{\circ} 16^{\prime} 31.9^{\prime \prime}$ & $<\mathrm{MDA}$ & $0.7(0.6)^{\mathrm{a}}$ & $<M D A$ & 9.5 & 1.2 & 0.6 \\
\hline 22 & $35^{\circ} 51^{\prime} 37.6^{\prime \prime}$ & $106^{\circ} 16^{\prime} 23.2^{\prime \prime}$ & $<$ MDA & $1.2(0.9)^{\mathrm{a}}$ & $<\mathrm{MDA}$ & 9.0 & 1.3 & 0.6 \\
\hline 23 & $35^{\circ} 51^{\prime} 39.2^{\prime \prime}$ & $106^{\circ} 16^{\prime} 27.8^{\prime \prime}$ & $<M D A$ & $1.0(0.8)^{a}$ & $<\mathrm{MDA}$ & 8.9 & 1.1 & 0.5 \\
\hline 24 & $35^{\circ} 51^{\prime} 40.1^{\prime \prime}$ & $106^{\circ} 15^{\prime} 49.6^{\prime \prime}$ & $<M D A$ & $6.5(11.5)^{b}$ & $<\mathrm{MDA}$ & 9.9 & 1.1 & 0.5 \\
\hline 25 & $35^{\circ} 51^{\prime} 37.9^{\prime \prime}$ & $106^{\circ} 16^{\prime} 19.8^{\prime \prime}$ & $<M D A$ & $1.3(1.1)^{\mathrm{a}}$ & $<M D A$ & 7.5 & 1.2 & 0.5 \\
\hline 27 & $35^{\circ} 51^{\prime} 40.4^{\prime \prime}$ & $106^{\circ} 15^{\prime} 31.1^{\prime \prime}$ & $<M D A$ & $1.0(0.8)^{\mathrm{a}}$ & $<\mathrm{MDA}$ & 9.3 & 1.6 & 0.8 \\
\hline
\end{tabular}

aSoil activity concentrations calculated using an exponential depth distribution for a $R=10-m$ circular area.

bSoil activity concentrations calculated using an exponential depth distribution for a $20-\times 2-m$ rectangular area.

nearly flat surfaces to rocky ravines. The estimated values for ${ }^{238} \mathrm{U}$ and ${ }^{232} \mathrm{Th}$ were found to range from $0.5-1.9 \mathrm{pCl} / \mathrm{g}(0.3-0.9 \mathrm{cps})$ and $0.8-1.9 \mathrm{pCi} / \mathrm{g}$ $(0.7-1.9 \mathrm{cps})$, respectively. For $40 \mathrm{~K}$, the activity was estimated to range from $12.5-38.7 \mathrm{pCi} / \mathrm{g}$ $(4.8-12.9 \mathrm{cps})$.
The uncertainty in the reported soil activity concentrations based on the extended source distribution model is estimated to be \pm 20 percent. It should be noted, however, that the model assumes a uniform flat terrain and the radionuclides are embedded only in the streambed. 
Table 8. Soil Activity Concentration for In Situ Data at Ten Site Canyon

\begin{tabular}{|c|c|c|c|c|c|c|c|c|}
\hline \multirow{2}{*}{$\begin{array}{l}\text { Site } \\
\text { No. }\end{array}$} & \multicolumn{2}{|c|}{ GPS Position } & \multicolumn{6}{|c|}{$\begin{array}{l}\text { Photopeak Counts per Second } \\
\text { (Soil Activity Concentration-pCi/g) }\end{array}$} \\
\hline & Latitude (N) & Longitude (W) & ${ }^{241} \mathrm{Am}$ & ${ }^{137} \mathrm{Cs}$ & ${ }^{60} \mathrm{Co}$ & ${ }^{40} \mathrm{~K}$ & 232Th & $238 \mathrm{U}$ \\
\hline 26 & $35^{\circ} 51^{\prime} 41.3^{\prime \prime}$ & $106^{\circ} 17^{\prime} 01.4^{\prime \prime}$ & $<M D A$ & $0.7(1.2)$ & $<M D A$ & 9.3 & 1.4 & 0.7 \\
\hline 28 & $35^{\circ} 51^{\prime} 41.5^{\prime \prime}$ & $106^{\circ} 17^{\prime} 08.0^{\prime \prime}$ & $<M D A$ & $<M D A$ & $<\mathrm{MDA}$ & 7.7 & 0.9 & 0.4 \\
\hline 29 & $35^{\circ} 51^{\prime} 42.0^{\prime \prime}$ & $106^{\circ} 17^{\prime} 43.3$ & $<M D A$ & $0.9(1.8)$ & $<\mathrm{MDA}$ & 9.5 & 1.2 & 0.5 \\
\hline 30 & $35^{\circ} 51^{\prime} 40.3^{\prime \prime}$ & $106^{\circ} 17^{\prime} 15.6^{\prime \prime}$ & $<M D A$ & $0.4(0.7)$ & $<\mathrm{MDA}$ & 8.9 & 0.9 & 0.5 \\
\hline 31 & $35^{\circ} 51^{\prime} 41.3^{\prime \prime}$ & $106^{\circ} 17^{\prime} 37.0^{\prime \prime}$ & $<\mathrm{MDA}$ & $1.6(3.2)$ & $<\mathrm{MDA}$ & 7.6 & 1.2 & 0.5 \\
\hline 32 & $35^{\circ} 51^{\prime} 42.2^{\prime \prime}$ & $106^{\circ} 17^{\prime} 17.9^{\prime \prime}$ & $<\mathrm{MDA}$ & $1.1(1.9)$ & $<\mathrm{MDA}$ & 8.2 & 0.9 & 0.4 \\
\hline 33 & $35^{\circ} 51^{\prime} 41.0^{\prime \prime}$ & $106^{\circ} 17^{\prime} 33.5^{\prime \prime}$ & $<\mathrm{MDA}$ & $0.8(1.6)$ & $<M D A$ & 7.4 & 0.9 & 0.4 \\
\hline 34 & $35^{\circ} 51^{\prime} 42.7^{\prime \prime}$ & $106^{\circ} 17^{\prime} 24.2^{\prime \prime}$ & $<M D A$ & $1.1(1.9)$ & $<\mathrm{MDA}$ & 8.2 & 1.1 & 0.5 \\
\hline 35 & $35^{\circ} 51^{\prime} 39.9^{\prime \prime}$ & $106^{\circ} 17^{\prime} 28.4^{\prime \prime}$ & $<$ MDA & $0.9(1.8)$ & $<M D A$ & 8.0 & 1.1 & 0.5 \\
\hline 36 & $35^{\circ} 51^{\prime} 38.5^{\prime \prime}$ & $106^{\circ} 17^{\prime} 27.6^{\prime \prime}$ & $<$ MDA & $1.2(2.1)$ & $<M D A$ & 9.1 & 1.2 & 0.5 \\
\hline 38 & $35^{\circ} 51^{\prime} 41.8^{\prime \prime}$ & $106^{\circ} 17^{\prime} 14.6^{\prime \prime}$ & $<$ MDA & $0.7(1.2)$ & $<M D A$ & 7.9 & 1.2 & 0.5 \\
\hline 40 & $35^{\circ} 51^{\prime} 43.5^{\prime \prime}$ & $106^{\circ} 17^{\prime} 11.7^{\prime \prime}$ & $<M D A$ & $2.5(4.4)$ & $<\mathrm{MDA}$ & 8.8 & 1.1 & 0.5 \\
\hline
\end{tabular}

a Soil activity concentrations calculated using an exponential depth distribution for a $20-\times 2-m$ rectangular area.

\subsection{Mortandad Canyón}

The results of the in situ measurements for Mortandad Canyon are presented in Table 7. The man-made radionuclides, ${ }^{241} \mathrm{Am},{ }^{137} \mathrm{Cs}$, and ${ }^{60} \mathrm{Co}$, were detected from Site 19 east (downstream direction) to the watercollection areas at Site 9. These sites exhibit laboratory contamination and are denoted by the red markers in Figure 1. Beginning at the upper end of the streambed from Site 19 to Site 12 , the streambed is a winding, narrow trench $6 \mathrm{ft}(2 \mathrm{~m})$ wide by $4 \mathrm{ft}(1.2 \mathrm{~m})$ deep. The streambed was generally sandy and slightly damp. Sites 9,10 , and 11 are man-made water-collection areas (sediment traps) developed by the laboratory. The collection areas are dry settling ponds of approximately 30 by $40 \mathrm{ft}$ ( 9 by $12 \mathrm{~m}$ ) with 8 to 10-ft (2.5- to 3-m) berms on 3 sides to collect and inhibit canyon water from flowing beyond the area.

Downstream from Site 9 , the streambed continues as a trench and gradually broadens to a shallow trough near the laboratory boundary at Site 1. No measurable contamination (except ${ }^{137} \mathrm{Cs}$ ), denoted by sites with black markers in Figure 1, was detected downstream from the settling ponds at Site 9 with the exception of Site 24. Site 24, denoted by a blue marker in Figure 1, indicates possible laboratory contamination of ${ }^{137} \mathrm{Cs}$ estimated before at $11.5 \mathrm{pCi} / \mathrm{g}$.
The origin of the ${ }^{137} \mathrm{Cs}$ levels detected downstream from Site 9 cannot be decisively determined; however, with the exception of Site 24, the values are consistent with worldwide fallout levels from atmospheric nuclear tests. It should also be noted that ${ }^{241} \mathrm{Am}$ is a decay product of plutonium-241 $\left({ }^{241} \mathrm{Pu}\right)$, which is present in trace quantities with reactor-separated plutonium-239 (239Pu). Therefore, the presence of ${ }^{241} \mathrm{Am}$ may indicate of low-level ${ }^{239} \mathrm{Pu}$ contamination.

\subsection{Ten Site Canyon}

The results of the in situ measurements for Ten Site Canyon are presented in Täble 8 . With the exception of Sites 31 and 40 , there was no evidence of ${ }^{241} \mathrm{Am}$, ${ }^{137} \mathrm{Cs}$, or ${ }^{60} \mathrm{Co}$ contamination in the canyon. Sites 31 and 40 are denoted by blue markers in Figure 1 and indicate possible laboratory contamination. Site 31 was located at the origin of the canyon where the in situ measurement yielded slightly elevated levels of ${ }^{137} \mathrm{Cs}$ at an estimated $3.2 \mathrm{pCi} / \mathrm{g}$. Site 40 was located at the base of a steep gravel road leading to the east end of the TA-35 complex. The spectral data acquired at this site indicate slightly elevated levels of ${ }^{137} \mathrm{Cs}$ at $4.4 \mathrm{pCi} / \mathrm{g}$. The remainder of the measurement sites yielded ${ }^{137} \mathrm{Cs}$ activity, estimates ranging from 0.6 to $1.9 \mathrm{pCi} / \mathrm{g}$. 
Table 9. Soil Activity Concentration for In Situ Data at DP Canyon

\begin{tabular}{|c|c|c|c|c|c|c|c|c|}
\hline \multirow{2}{*}{$\begin{array}{l}\text { Site } \\
\text { No. }\end{array}$} & \multicolumn{2}{|c|}{ GPS Position } & \multicolumn{6}{|c|}{$\begin{array}{l}\text { Photopeak Counts per Second } \\
\text { (Soil Activity Concentration-pCl/g) }\end{array}$} \\
\hline & Latitude (N) & Longitude (W) & ${ }^{241} \mathrm{Am}$ & ${ }^{137} \mathrm{Cs}$ & ${ }^{60} \mathrm{Co}$ & ${ }^{40} K$ & $232 \mathrm{Th}$ & $238 \mathrm{U}$ \\
\hline 37 & $35^{\circ} 52^{\prime} 41.8^{\prime \prime}$ & $106^{\circ} 16^{\prime} 24.4^{\prime \prime}$ & $<$ MDA & $5.4(10.8)$ & $<M D A$ & 7.2 & 0.9 & 0.4 \\
\hline 39 & $35^{\circ} 52^{\prime} 40.9^{\prime \prime}$ & $106^{\circ} 16^{\prime} 11.3^{\prime \prime}$ & $<\mathrm{MDA}$ & $16.6(33.2)$ & $<M D A$ & 7.9 & 1.1 & 0.6 \\
\hline 41 & $35^{\circ} 52^{\prime} 37.3^{\prime \prime}$ & $106^{\circ} 16^{\prime} 02.8^{\prime \prime}$ & $<M D A$ & $13.7(27.4)$ & $<M D A$ & 11.7 & 1.8 & 0.8 \\
\hline 42 & $35^{\circ} 52^{\prime} 38.7^{\prime \prime}$ & $106^{\circ} 16^{\prime} 18.4^{\prime \prime}$ & $4.5(13.3)$ & $20.8(36.8)$ & $<M D A$ & 8.1 & 1.1 & 0.5 \\
\hline 43 & $35^{\circ} 52^{\prime} 40.9^{\prime \prime}$ & $106^{\circ} 16^{\prime 2} 28.2^{\prime \prime}$ & $<\mathrm{MDA}$ & $1.9(3.82)$ & $<M D A$ & 5.8 & 0.9 & 0.3 \\
\hline 44 & $35^{\circ} 52^{\prime} 39.9^{\prime \prime}$ & $106^{\circ} 16^{\prime} 11.3^{\prime \prime}$ & $<M D A$ & $9.7(17.2)$ & $<M D A$ & 9.8 & 1.3 & 0.7 \\
\hline 45 & $35^{\circ} 52^{\prime} 40.6^{\prime \prime}$ & $106^{\circ} 16^{\prime} 26.6^{\prime \prime}$ & $8.3(26.3)$ & $11.9(23.8)$ & $<\mathrm{MDA}$ & 4.8 & 0.8 & 0.3 \\
\hline 46 & $35^{\circ} 52^{\prime} 41.6^{\prime \prime}$ & $106^{\circ} 16^{\prime} 25.8^{\prime \prime}$ & $<\mathrm{MDA}$ & $6.5(11.5)$ & $<M D A$ & 8.6 & 1.2 & 0.5 \\
\hline 47 & $35^{\circ} 52^{\prime} 43.9^{\prime \prime}$ & $106^{\circ} 16^{\prime} 33.0^{\prime \prime}$ & $<M D A$ & $1.8(3.6)$ & $<M D A$ & 8.8 & 1.0 & 0.5 \\
\hline 48 & $35^{\circ} 52^{\prime} 40.2^{\prime \prime}$ & $106^{\circ} 16^{\prime} 31.1^{\prime \prime}$ & $77.7(230.7)$ & $81.7(144.6)$ & $<M D A$ & 7.8 & 1.2 & 0.5 \\
\hline 49 & $35^{\circ} 52^{\prime} 44.6^{\prime \prime}$ & $106^{\circ} 16^{\prime} 35.2^{\prime \prime}$ & $<M D A$ & $<M D A$ & $<\mathrm{MDA}$ & 8.9 & 1.4 & 0.6 \\
\hline 50 & $35^{\circ} 52^{\prime} 39.5^{\prime \prime}$ & $106^{\circ} 16^{\prime} 29.5^{\prime \prime}$ & $97.8(290.4)$ & $138.7(245.4)$ & $<\mathrm{MDA}$ & 8.6 & 1.3 & 0.5 \\
\hline 51 & $35^{\circ} 52^{\prime} 44.4^{\prime \prime}$ & $106^{\circ} 16^{\prime} 42.5^{\prime \prime}$ & $<M D A$ & $<M D A$ & $<M D A$ & 8.6 & 1.3 & 0.6 \\
\hline 52 & $35^{\circ} 52^{\prime} 39.7^{\prime \prime}$ & $106^{\circ} 16^{\prime} 28.3^{\prime \prime}$ & $<\mathrm{MDA}$ & $20.6(36.4)$ & $<M D A$ & 8.8 & 1.3 & 0.5 \\
\hline 53 & $35^{\circ} 52^{\prime} 45.7^{\prime \prime}$ & $106^{\circ} 16^{\prime} 42.4^{\prime \prime}$ & $<M D A$ & $<\mathrm{MDA}$ & $<M D A$ & 8.6 & 1.3 & 0.6 \\
\hline 54 & $35^{\circ} 52^{\prime} 38.8^{\prime \prime}$ & $106^{\circ} 16^{\prime} 28.1^{\prime \prime}$ & $<M D A$ & $4.5(7.9)$ & $<M D A$ & 9.2 & 1.3 & 0.6 \\
\hline 55 & $35^{\circ} 52^{\prime} 48.6^{\prime \prime}$ & $106^{\circ} 16^{\prime} 53.1^{\prime \prime}$ & $<M D A$ & $<M D A$ & $<M D A$ & 9.0 & 1.2 & 0.6 \\
\hline 56 & $35^{\circ} 52^{\prime} 25.9^{\prime \prime}$ & $106^{\circ} 15^{\prime} 35.2^{\prime \prime}$ & $<M D A$ & $13.1(23.1)$ & $<\mathrm{MDA}$ & 12.1 & 1.8 & 0.9 \\
\hline 57 & $35^{\circ} 52^{\prime} 41.7^{\prime \prime}$ & $106^{\circ} 16^{\prime} 58.7^{\prime \prime}$ & $<\mathrm{MDA}$ & $0.5(1.0)$ & $<M D A$ & 8.8 & 1.2 & 0.6 \\
\hline 58 & $35^{\circ} 52^{\prime} 27.0^{\prime \prime}$ & $106^{\circ} 15^{\prime} 36.7^{\prime \prime}$ & $<\mathrm{MDA}$ & $11.4(20.1)$ & $<\mathrm{MDA}$ & 12.9 & 1.6 & 0.8 \\
\hline 59 & $35^{\circ} 52^{\prime} 49.7^{\prime \prime}$ & $106^{\circ} 1707.9^{\prime \prime}$ & $<\mathrm{MDA}$ & $<\mathrm{MDA}$ & $<\mathrm{MDA}$ & 10.2 & 1.3 & 0.6 \\
\hline 60 & $35^{\circ} 52^{\prime} 22.5^{\prime \prime}$ & $106^{\circ} 15^{\prime} 32.2^{\prime \prime}$ & $<\mathrm{MDA}$ & $<\mathrm{MDA}$ & $<\mathrm{MDA}$ & 9.6 & 1.6 & 0.4 \\
\hline 61 & $35^{\circ} 52^{\prime} 37.0^{\prime \prime}$ & $106^{\circ} 16^{\prime} 16.0^{\prime \prime}$ & $<$ MDA & $1.0(2.0)$ & $<M D A$ & 7.1 & 1.0 & 0.5 \\
\hline 62 & $35^{\circ} 52^{\prime} 36.4^{\prime \prime}$ & $106^{\circ} 16^{\prime} 21.3^{\prime \prime}$ & $<M D A$ & $0.5(0.9)$ & $<M D A$ & 9.8 & 1.4 & 0.6 \\
\hline 63 & $35^{\circ} 52^{\prime} 25.2^{\prime \prime}$ & $106^{\circ} 15^{\prime} 35.5^{\prime \prime}$ & $<\mathrm{MDA}$ & $6.5(13.0)$ & $<\mathrm{MDA}$ & 9.7 & 1.3 & 0.7 \\
\hline 64 & $35^{\circ} 52^{\prime} 30.2^{\prime \prime}$ & $106^{\circ} 16^{\prime} 20.2^{\prime \prime}$ & $<\mathrm{MDA}$ & $<M D A$ & $<M D A$ & 8.9 & 1.1 & 0.6 \\
\hline 65 & $35^{\circ} 52^{\prime} 37.5^{\prime \prime}$ & $106^{\circ} 16^{\prime} 29.9^{\prime \prime}$ & $9.2(29.2)$ & $27.7(55.4)$ & $<$ MDA & 7.2 & 0.9 & 0.4 \\
\hline
\end{tabular}

a Soil activity concentrations calculated using an exponential depth distribution for a 20- $\times 2-m$ rectangular area.

\subsection{DP Canyon}

Only two of three man-made radionuclides of interest, ${ }^{241} \mathrm{Am}$ and ${ }^{137} \mathrm{Cs}$, were detected in DP Canyon measurements. Sites $49,51,53,55,57$, and 59 , located at the western end of the canyon and indicated by black markers in Figure 2, show no evidence for laboratory contamination. East of Site 49 was a $150-$ by 150-ft (46- by 46-m) fenced area (designated with radiation control signs) that was contaminated with 
radionuclides as a result of past waste-water discharges and overflow from the TA-21 complex. Laboratory contamination from $241 \mathrm{Am}$ and ${ }^{137} \mathrm{Cs}$ was detected at Sites $42,45,48,50$, and 65. These sites, denoted by red markers in Figure 2 , were located in 8 -ft-wide by 6 -ft-deep (2.5- by $2-\mathrm{m}$ ) trenches near or adjacent to the fenced area.

The remainder of the measurement sites, except for Sites 60, 61, 62, and 64, from below the fenced area to the confluence with the Los Alamos Canyon, denoted by blue markers in Figure 2, exhibited possible laboratory contamination from ${ }^{137} \mathrm{Cs}$. Below Site 41 , the canyon becomes very rocky and descends rapidly (over $300 \mathrm{ft}[90 \mathrm{~m}]$ ) to the confluence with the Los Alamos Canyon. Site 60 was located on the gravel roadway in Los Alamos Canyon and showed no evidence of contamination. Sites 61,62 , and 64 were located at drainage points along the main roadway on the mesa and showed no evidence of ${ }^{241} \mathrm{Am},{ }^{137} \mathrm{Cs}$, or ${ }^{60} \mathrm{Co}$ contamination.

\subsection{CONCLUSION}

An in situ radiological survey was conducted at Mortandad, Ten Site, and DP Canyons and other locations at LANL during August 19-30, 1996. A total of 65 measurements were conducted in the streambeds traversing the canyons. The survey was conducted in support of the laboratory environmental restoration programs and measured the quantities of radionuclides that remain in the canyons as a result of past laboratory operations. The three man-made radionuclides detected were ${ }^{241} \mathrm{Am},{ }^{137} \mathrm{Cs}$, and ${ }^{60} \mathrm{Co}$. 
APPENDIX A

\section{SURVEY PARAMETERS}

Survey Location: Los Alamos National Laboratory Los Alamos, New Mexico

Survey Sites: Mortandad Canyon

Ten Site Canyon

DP Canyon

Survey Dates:

August 19-30, 1996

Equipment:

Detector 1: HPGe n-type (101 percent) EG\&G ORTEC Serial No. 34TN20879

Detector 2: HPGe n-type (90 percent) EG\&G ORTEC Serial No. 34TN30888

Measurement: $\quad 900$ seconds on 1-m tripod

Positioning System: Global Positioning System

Field Team 1:

S. Mukhopadhyay, T.A. Reh, J.L. Butler

Field Team 2:

D.R. Bowman, C.N. Sofologis, D.F. Farmer 


\section{REFERENCES}

1. Maurer, R.J. [Private communication with C. Mason, LANL Project Manager for DP Canyon, and R. Koch, SAIC Project Manager for Mortandad Canyon and Ten Site Canyon]. 1996.

2. "Gamma Data Reduction." [Gamma-ray analysis and identification software. A Kocher-based radionuclide library containing over 340 gamma-ray lines was included with the software.] Version 6.1, 1989; Quantum, Inc.

3. Beck, H.L.; J. DeCampo; and C. Gogolak. In Siru Ge (Li) and NaI(Tl) Gamma Ray Spectrometry. Report No. HASL-258, TID-4500, 1972; U.S. AEC Health and Safety Laboratory, New York, New York.

4. Reiman, R.T. In Situ Surveys of the U.S. Department of Energy's Rocky Flats Plant-Golden, Colorado. Report No. EGG-10617-1129, 1991; EG\&G/EM, Las Vegas, Nevada.

5. Bowman, D. [Memorandum to B. Best, et al., Bechtel Nevada; subject: Finite Area Conversion Factors, F23D-DB-97-159]. September 1997

6. Beck, H. "Environmental Gamma Radiation from Deposited Fission Products, 1960-1964." Health Physics, 12:313-322; 1966. 
DOE/DP

J. A. Weidner, CDR USN

DOE/NSIC

R. S. Scott

DOE/NV

T. A. Cooper

\section{LANL}

R. Koch

C. Mason

\section{BN}

C. M. Bluitt

P. J. Blumenthal

D. R. Bowman

J. L. Butler

D. F. Farmer
(1)

1)

)

(3)

(3)

\section{LIBRARIES}

DOE/NVPublic Reading Facility

RSL-A

RSL-N

TIRC

(1)

(1)

(1)

RSL-A

RSL-N

RSL-N

RSL-A

LVAO

RSL-N

RSL-N

RSL-A

RSL-N

LVAO

RSL-N

RSL-A

RSL-N

(1)

(1)

(1)

RSL-A

RSL-N

RSL-A

RSL-A
(1)

(1)

(1)

(1)

1)

\section{OSTI}

